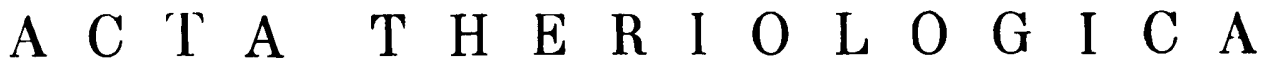

VOL. XIII, 12: 177-218.

BIAŁOWIEŻA

20.V.1968

\author{
Mieczysław W E G R Z Y N
}

\section{Blood-Vascular System of the European bison. I. Morphology oi the Heart}

\author{
Bisoniana XXXVI
}

[With 18 Figs., 11 Tables and Plate I-III]

\begin{abstract}
The heart topography, pericardial relations, shape, size, weight and morphology of the heart as well as heart measurements were studied in 37 male and female European bisons of different age. In the European bison the heart usually is situated in the space between the posterior borders of the $3 \mathrm{rd}$ and 6 th rib. Its apex is on the level of the $6-7$ th costal cartilages. The pericardium is attached to the sternum with two ligg. sternopericardiaca (inserted on the level of the 6-7th costal cartilagines) and one lig. phrenicopericardiacum. The heart of an adult bison is cone shaped markedly widened at the base, relatively low and pronouncedly flattened laterally with the apex usually bent slightly toward the posterior. Conus arteriosus dexter is situated high with relation to ventriculus proprius of the right ventricle. The heart measurements are much larger in the European bison than in the domestic cattle, except for the posterior border which is shorter in the bison. In male bisons the mean heart weigth was $3.057 \mathrm{~kg}$, or $0.495^{\circ} \%$ of body weight. The tricuspid valve is composed of $3-7$ cusps, most frequently 3 cardinal cusps and one accessory cusp. The bicuspid valve is composed of 4-9 cusps, 2 cardinal and several accessory. In the right ventricle some chordae tendineae were extending directly from septum interventriculare to cuspis septalis of the tricuspid valve. Both $\mathrm{mm}$. papillares of the left ventricle usually send strong trabeculae carneae to the lateral ventricle wall, at the base of the cusps of the bicuspid valve.
\end{abstract}

I. Introduction

II. Material and method

III. Results

1. Topography of the heart . . . . . . . . . . . . . 181

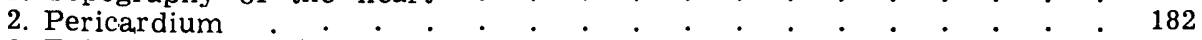

3. External morphology of the heart 183

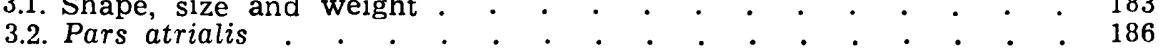

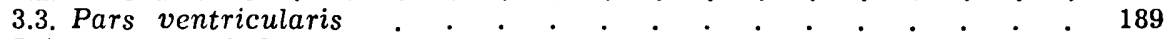

4. Internal morphology of the heart
4.1. The right atrium

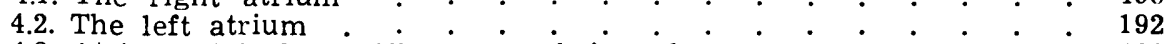

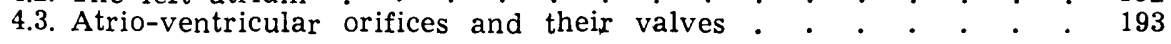




\section{INTRODUCTION}

This work is a part of the complex study on the anatomy of the European bison which is carried out at the European Bison Research Center in Warsaw under the guidance of Professor K. K r y siak. This paper is first in the series describing the blood-vascular system and concerns the heart as its central organ.

Table 1.

Listing of the material studied.

\begin{tabular}{|c|c|c|c|c|c|c|c|c|c|c|c|}
\hline No. & 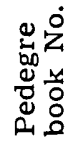 & Name & \multicolumn{3}{|c|}{ Age $^{*}$} & No. & 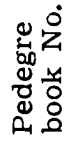 & Name & \multicolumn{3}{|c|}{ Age* } \\
\hline 1 & 1372 & Pop & - & - & 4 & 1 & 1517 & $\mathrm{Pu} \mathrm{I}$ & - & - & 1 \\
\hline 2 & - & Plakat & - & 1 & 9 & 2 & 1564 & Pomila & - & 1 & 12 \\
\hline 3 & 1304 & Pomian & - & 1 & 19 & **3 & 857 & Pleśnianka & 1 & 7 & 19 \\
\hline 4 & 1280 & Porucznik & - & 5 & 8 & $* * 4$ & 793 & Pugorka & 1 & 8 & 26 \\
\hline 5 & 1292 & Plon & - & 10 & - & ${ }^{* *} 5$ & 763 & Puganka & 2 & 2 & 12 \\
\hline 6 & 1454 & Zon & 1 & 1 & 18 & 6 & 1148 & Puzota & 2 & 8 & 18 \\
\hline 7 & 1459 & Poronin & 2 & - & 8 & 7 & 977 & Powaga & 7 & 7 & 8 \\
\hline 8 & 1151 & Puck & 4 & - & 25 & 8 & 770 & Popielica & 12 & 1 & 12 \\
\hline 9 & 1212 & Puslon & 4 & 9 & 3 & 9 & 724 & Puszynka & 15 & 4 & 16 \\
\hline 10 & 1034 & Potok & 4 & 9 & 20 & **10 & 219 & Planarie & 18 & 5 & 1 \\
\hline 11 & 1208 & Puzor & 5 & 7 & 2 & 11 & 596 & Putka & 20 & 4 & 14 \\
\hline 12 & 1087 & Pug & 6 & 1 & 26 & 12 & 524 & Beste & 23 & 8 & 18 \\
\hline 13 & 1082 & Pozew & 6 & 4 & 13 & & & & & & \\
\hline 14 & 1026 & Putar & 6 & 4 & 24 & & - & Heart No. 33 & & & \\
\hline$* 15$ & 694 & Pustelnik & 8 & 4 & 21 & $* * 2$ & - & & & & \\
\hline 16 & 785 & Pluszcz & 10 & 5 & 9 & $* * 3$ & - & Heart No. 35 & & & \\
\hline **17 & 597 & Punkt & 10 & 6 & 24 & $* * 4$ & - & Heart No. 36 & & & \\
\hline 18 & 879 & Stor-per & 11 & 5 & 28 & $*^{* * 5}$ & - & Heart No. 37 & & & \\
\hline 19 & 789 & Plamiec & 14 & 4 & 18 & & & & & & \\
\hline 20 & 575 & Plato & 17 & 3 & 29 & & & & & & \\
\hline
\end{tabular}

*) Years, months, days. ${ }^{* *}$ ) Material from collection of Dr. J. K a łużniacki.

The only published data on the morphology of the European bison heart are these of Albrecht (1957) who studied the heart in Bovinae and described one isolated heart of an approximately two year old European bison. Naturally, he could not consider the topography, pericardium relations or the morphology of a fully formed heart of an adult animal. His results required comparison with larger and diversified material collected from individuals of different sex and age.

The present results were compared with the situation in other ruminants and especially in domestic cattle.

Studies on the morphology of the European bison heart were started by a former staff member of our Department, the late Dr. Jan Kałuż $\mathrm{i} a \mathrm{cki}$, who died in 1955. Eleven hearts collected by him were included in the materials of this study and some of his observations are quoted in the text. 


\section{MATERIAL AND METHOD}

The studies were carried out on 37 bisons (Table 1) which did not have any macroscopic anatomo-pathological changes of the heart, the lungs the aorta or the kidneys.

The material was usually fixed with an aqueous solution of formalin or a mixture with denatured alcohol introduced under pressure through the artery into the whole carcass (Pilarski et al. 1967).

The study involved topography of the heart within the thoracic cavity, pericardial relations, shape, size and weight as well as morphologic description with appropriate measurements. The topography of the heart was determined in the fixed carcass and documented by both descriptions and photographs.

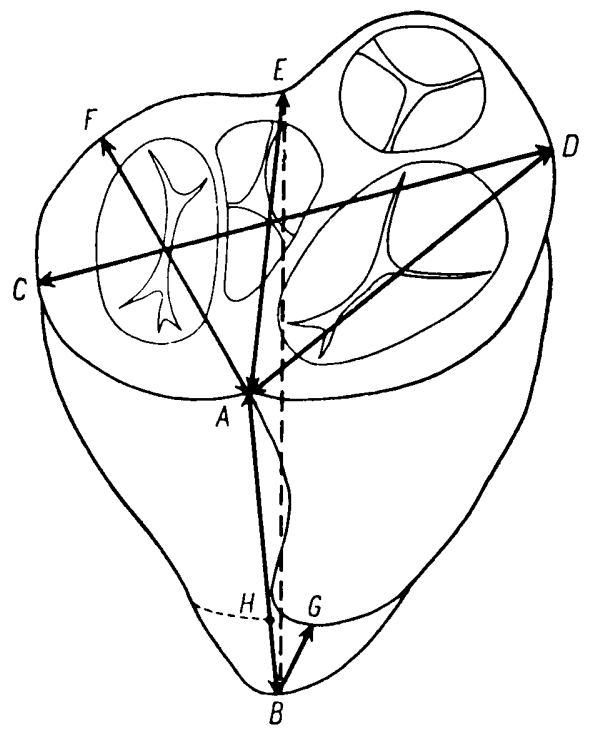

Fig. 1. Scheme of the points of liner measurements of the heart.

Most of the measurements were taken following the methods of $\mathrm{Schubert}$ (1909) and Ple mia n nik ov (1954c) designed for cattle and goats (Fig. 1). Following the assumptoins of these authors only pars ventricularis was measured. The employed method of fixing the whole carcass allows measuring the whole heart, but only measurements of pars ventricularis were used for comparative purposes.

The following measurements were taken on pars ventricularis of the heart:

1. Height of the left surface i.e. the left ventricle (Fig. 1, B-E)

2. Height of the right surface $(A-B)$

3. Height of the right ventricle $(A-H)$

4. Height of the heart apex $(B-G)$

5. The minimal width $(\mathrm{A}-\mathrm{E})$

6. The maximal width (C-D)

7. Width of the left ventricle $(A-F)$

8. Width of the right ventricle $(A-D)$

9. Heart circumference in the broadest place, beneath the coronary groove

10. Circumference of the left ventricle

11. Circumference of the right ventricle 
12. Length of the anterior border

13. Length of the posterior border

14. Thickness of the right ventricle wall ${ }^{2}$ )

15. Thickness of the left ventricle wall ${ }^{1}$ ).

The measurements $1-3$ and 5-8 were taken with compasses, measurements 4, 14 and 15 - with a nonius slide and measurements $9-13$ with a flaxen thread.

Moreover, many measurements of both atriums and the valve apparatus of the heart are included in the descriptive part of this work. The weight of the heart was determined while it was fresh; after removing pericardium and reducing the length of the arteries to $5 \mathrm{~cm}$ and the length of the veins to $2 \mathrm{~cm}$. As data on the weight of some of studied bisons were not available, their body length was measured according to $\mathrm{Piegkos}$ et al. (1958) and given in tables 2 and 3 for comparison.

To study the anatomy of the heart several incisions were made using a modified method of Ž edenov (1941) and partially that of Vermes (1926). The incisions were made in three stages.

1-st stage. Opening of the right atrium, right auricle and venae cavae. First incision (Fig. 2A.1) was made through the dorsal wall of atrium, from vena cava cranialis to $v$. cava caudalis. The following two incisions (Fig. 2A.2, 3) were through the lower walls of both $v v$. cavae, down through the atrium wall to the level of the coronary groove and then parallel to it. Fourth incision (Fig. 2A.4) was through the lateral wall of the right auricle to its apex.
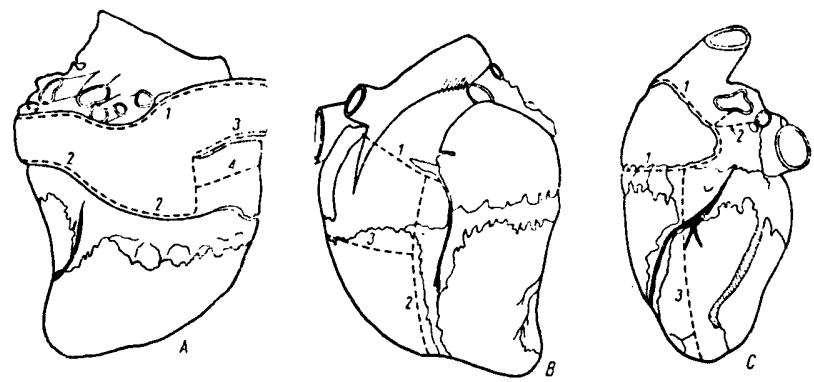

Fig. 2. Scheme of the incisions on: A - right atrium, right auricle and vv. cavae, $\mathrm{B}$ - right ventricle, $\mathrm{C}-$ left atrium, $v v$. pulmonales and left ventricle.

2-nd stage. Opening of the right ventricle. First incision (Fig. 2B. 1) was transverse through the walls of the pulmonary artery and aorta above their valves. Second incision (Fig. 2B. 2) was through the pulmonary artery between the semilunar cusps of its valve and then through the right ventricle to the apex along the left longitudinal groove. Third cut (Fig. 2B. 3) was beginning at the right atrioventricular orifice and was perpendicular to the second incision.

3 -rd stage. Opening the left auricle, $v v$. pulmonales and the left ventricle. The left auricle was removed with the first circuitous incision (Fig. 2C. 1). Second incision (Fig. 2C. 2) was made through the dorsal wall of artium between vv. pulmonales. Third was the incision of the left ventricle (Fig. 2C, 3), from atrio-ventri-

1) The measurements were taken on three levels: in the thickest spot i.e. beneath the coronary groove, in the center of ventricle height and on the apex. The measurement in the thickest place also included the thickness of trabeculae carneae which are present there. 
cular orifice to the apex, between two $m m$. pectinati. This cut began between cuspis parietalis and cuspis accessorius sinister of the biscupid valve. Fourth incision was opening the aortic orifice between the semilunar cusps of its valve.

From a heart of an adult ${ }^{2}$ ) individual many transverse sections were made (Fig. 18) to illustrate graphically the hearts shape. The sections were made perpendicularly to the long axis of the heart, every $2 \mathrm{~cm}$ as measured on the level of the right longitudinal groove.

The quoted measures of the blood vessels were computed from the formula: diameter $=$ circumference: $\pi$ (S c h u ber t, 1909, P a l m g r e n, 1928a) after measuring the circumference of the vessels. The circumference was measured on the internal surface of the previously cut vessel.

\section{RESULTS}

\section{Topography of the Heart}

The heart surrounded by pericardium is located in mediastinum above the sternum (Phot. 1, 2, 3). It occupies space between the hind borders of the $3 \mathrm{rd}$ and 6 th rib. Its apex is directed posteriorly, left from the median plane of the body and it is on the level of 7 th- -8 th costal cartilage. The anterior border of the heart (Phot. 5, 6) is strongly convex. Its lower part faces the sternum and the upper part faces the anterior. The posterior border (Phot. 5, 6) is slightly concave and directed posteriorly, toward the diaphragm.

The long axis of the heart (Phot. 2, 4) and the sternum form an angle open toward the posterior. In adult specimens this angle is from 62 to $65^{\circ}$, while in the younger animals it is smaller (Bison "Zon «, about 1 year old $-55^{\circ}$, "Poronin " about 2 years old $-60^{\circ}$ ).

The heart together with pericardium is covered by the lungs except the apex and small areas adjacent to the ribs. On the left (Phot. 1) it is uncovered on the width of the fourth $\mathrm{rib}$ and fourth intercostal space; in adult animals $11-14 \mathrm{~cm}$ above the junction of the ribs with costal cartilagines. Also on the right (Phot. 3) the heart with pericardium is adjacent to the chest wall and is not covered by the lungs at the level of the $4-5$ th rib. In young individuals these aspects of heart topography were similar; only in one case (1 day old bison) was pericardium with the heart completely covered by the lungs on the right side.

Variation. In the studied material the topography of the heart in relation to the ribs was quite variable. The heart was shifted toward the anterior, between the anterior borders of the $3 \mathrm{rd}$ and the 6 th rib

2) According to data of Empel \& Roskosz (1963) European bisons were considered adult when at least 5 years old. 
( 3 cases $-21.4 \%$ ) or toward the posterior, between the anterior borders of the 4 th and the 7 th rib ( 2 cases $-14.3 \%)$. In the former group one individual had 13 pairs of ribs instead of the usual 14 pairs.

\section{Pericardium}

In the European bison the line of transition of lamina parietalis into lamina visceralis pericardi (Phot. 5-8) goes along $v$. cava cranialis and truncus brachiocephalicus com. (Phot. 7-1), in adult individuals 11$12 \mathrm{~cm}$ from the coronary groove. Then it passes to the left, goes along the pulmonary artery, reaches the left atrium and crosses obliquely $v$. azygos sinistra (Phot. 5, 8-1'). On the left atrium the transition line is below $v v$. pulmonales (Phot. 8-1'). Further, it circles round v. cava caudalis from below, arches up on the right atrium and opens into $v$. cava cranialis (Phot. 6-1').

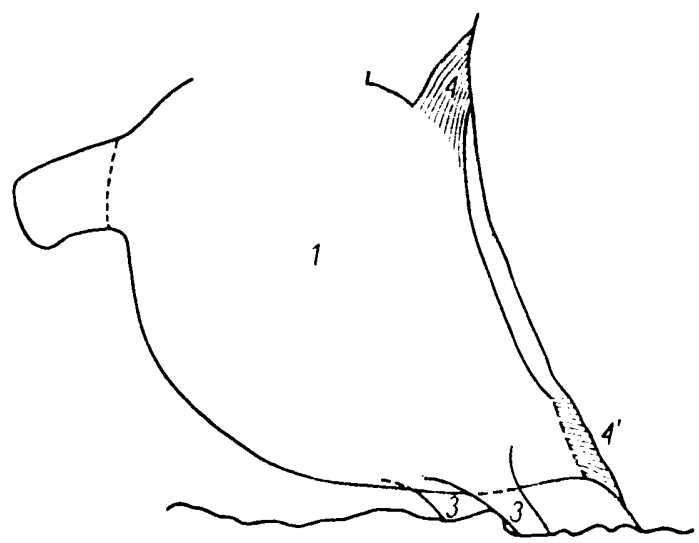

Fig. 3. Scheme of insertions and course of the ligaments connecting pericardium with sternum and diaphragm.

Sinus transversus pericardii lies between the pulmonary artery and the aorta on one side and the heart atria on the other. In adult individuals it is about $18 \mathrm{~cm}$ long.

The pericardium is fastened with paired ligg. sternopericardiaca and lig. phrenicopericardiacum. Pericardium is connected with the sternum by ligg. sternopericardiaca (Phot. 4, Fig. 3-3). The right sterno-pericardiac ligament is connected with the sternum on the level of the 6 th costal cartilage. However, the left sterno-pericardiac ligament is shifted posteriorly and has an insertion on the level of the 6 do the 7 th costal cartilage. In adult individuals these ligaments were $2-5 \mathrm{~cm}$ high and $2-4 \mathrm{~cm}$ wide. 
Variation. Occasionally sterno-pericardiac ligaments did not form a continuous wall but had large openings. In one case $(7.1 \%)$ each ligament was divided into two parts: weaker anterior part and stronger posterior part.

On the level of the heart coronary groove pericardium is connected with the diaphragm by lig. phrenicopericardiacum (Phot. 4, Fig. 3-4). In adult animals it was $1.2-2.2 \mathrm{~cm}$ high and $0.5-0.7 \mathrm{~cm}$ long.

Variation. In one case $(7.1 \%)$ lig. phrenicopericardiacum lay lower than usual, in the middle of the posterior heart border. In another case (Phot. 4-4') there was an additional strong lig. phrenicopericardiacum in the vinicity of the heart apex. It was $5.5 \mathrm{~cm}$ high and $1.5 \mathrm{~cm}$ long.

\section{External Morphology ${ }^{3}$ ) of the Heart}

\subsection{Shape, Size and Weight}

Studies on the shape and size of the fresh heart usually concern only pars ventricularis which does not collapse after isolating the heart from the carcass and determines the shape of the whole organ.

The heart of the European bison has a shape of a short laterally flattened cone, widened at the base (Phot. 2, 5-8). The apex is usually blunt and most frequently it is bent posteriorly.

The base of pars ventricularis of the heart is oblique in relation to its long axis. The longest distance between the base and the apex is on the anterior left surface of the heart and the shortest is on the level of the posterior border. This is indicated by the measurements of the height of the left and the right surface and the length of the anterior and the posterior border (Table 2).

The lateral flattening of the heart is well seen in the middle of the ventricles height (Fig. 18-C, D). However, close to the base the cross-section of the heart becomes oval, strongly widened in the anterior part (Fig. 18-A, B). The cross-section of the apex made immediately below the right ventricle is round (Fig. 18-F, G).

A high position of conus arteriosus dexter (Phot. 7-62; Table 2) seems characteristic of the bison heart.

Measurements of the heart were made on the fixed material. Either the heart was placed in aqueous solution of formalin (group II) or the whole carcass was injected through the artieries with preserving solutions (group I - Table 2).

3) The terms »external structure" and "internal structure" were used according to earlier authors describing the mammalian heart - H u v y e r (1926). W a ldm ei er (1828), G s c h w end (1931), S p a n gl (1932). 
Table 2.

External measurements of the heart of the European bison ( $\mathrm{mm}$ ).

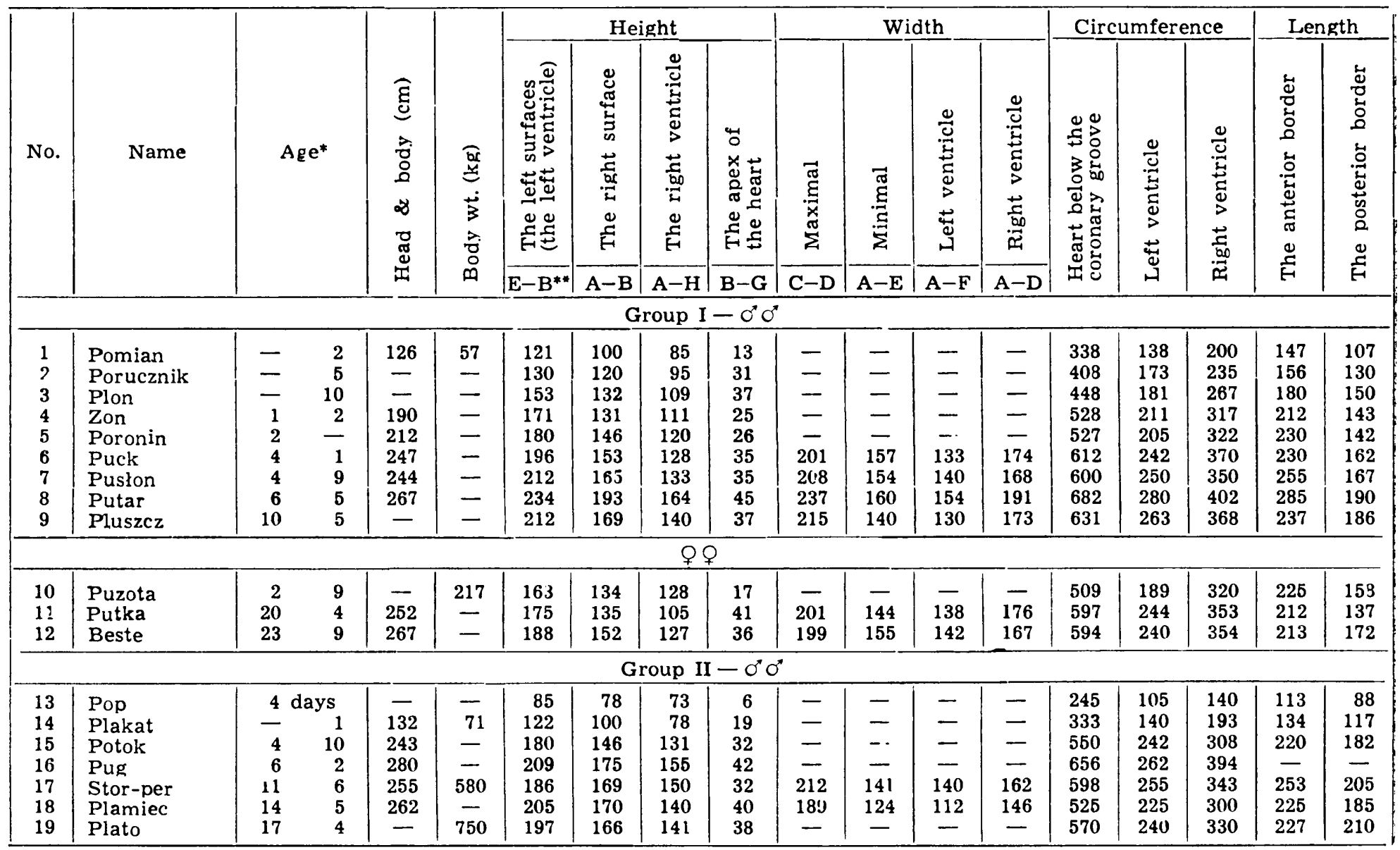

*) Age in years and months. ${ }^{* *}$ ) Points of measurements after fig. 1. 


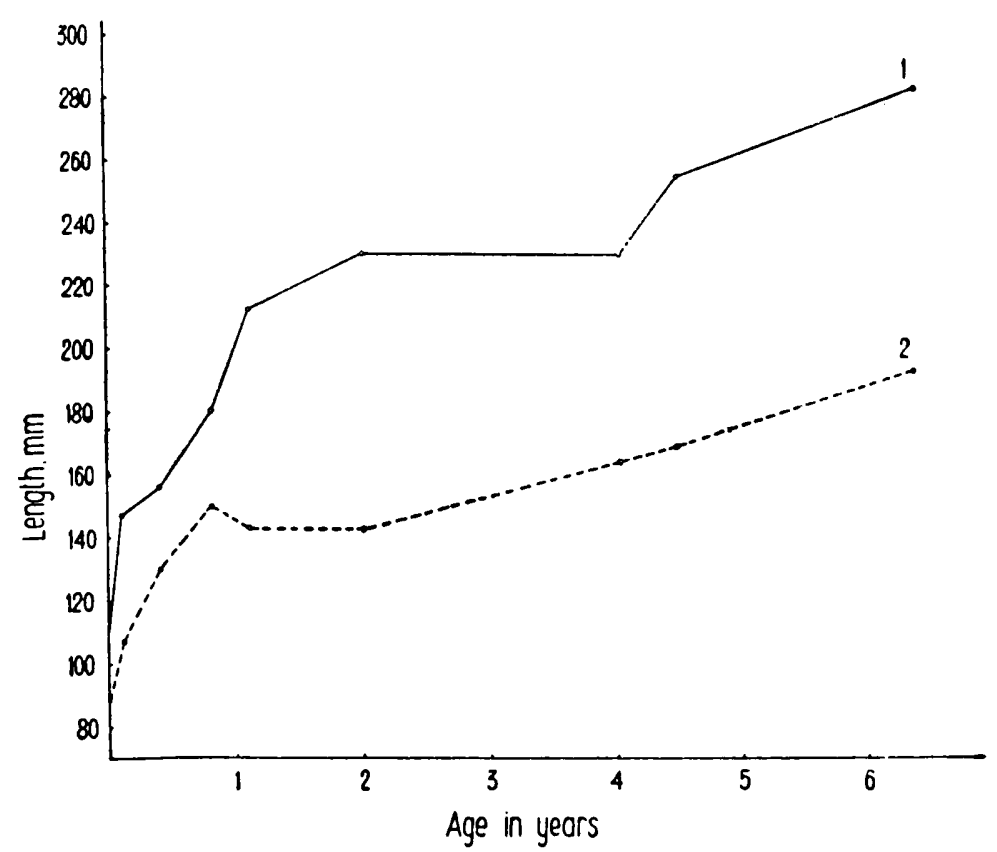

Fig. 4. Differences in the growth of the length of the anterior heart border (1) and posterior heart border (2) in male bisons during post-embryonic development.

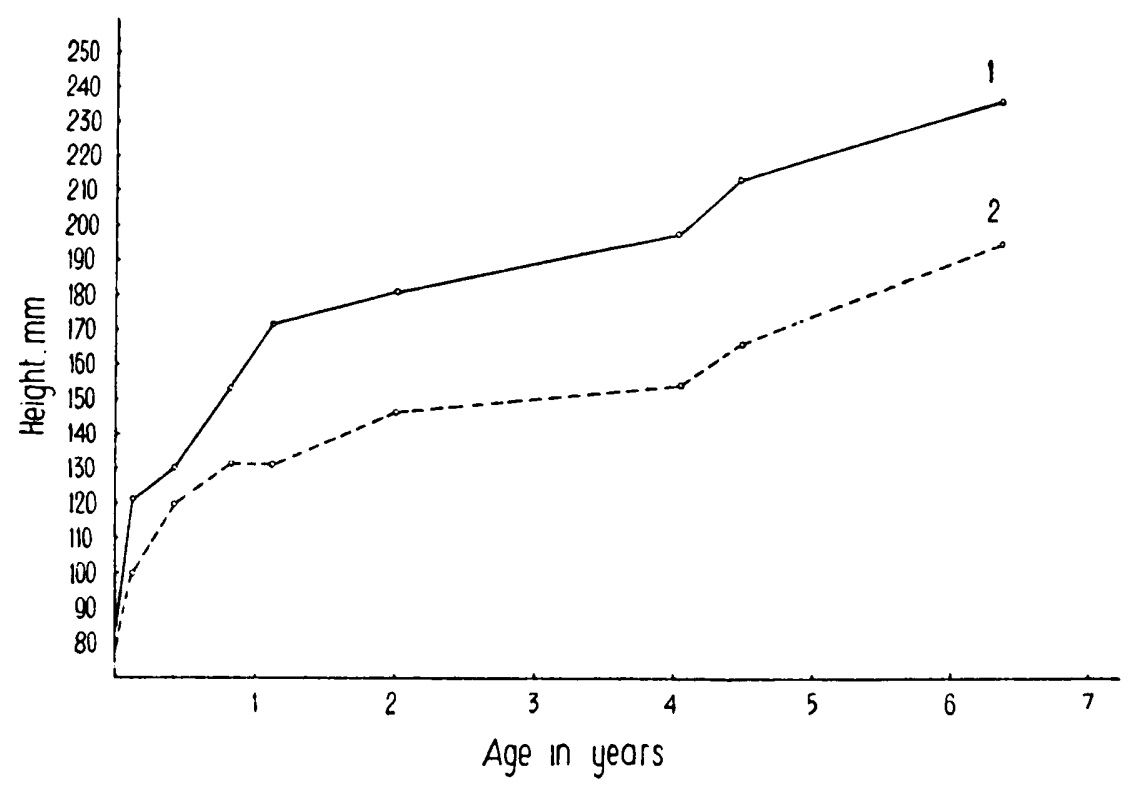

Fig. 5. Differences in the growth of the height of the left heart surface (1) and the right heart surface (2) in male bisons during postnatal development. 
During the postnatal development the heart of the European bison not only increases but also changes its shape. The difference between the length of the anterior and the posterior border is progressively increasing (Fig. 4), similarly to the difference between the heigh of the left and the right surface of the heart (Fig. 5). Consequently, the plane of the pars ventricularis base gradually changes its angle with the long axis of the heart during postnatal development.

Table 3.

The weight of the studied bison hearts $\left(\sigma^{7} \sigma^{x}\right)$.

\begin{tabular}{|c|c|c|c|c|c|c|c|c|c|}
\hline \multirow[b]{2}{*}{ No. } & \multirow[b]{2}{*}{ Name } & \multirow{2}{*}{\multicolumn{2}{|c|}{$\begin{array}{c}\text { Age } \\
\text { yrs. months }\end{array}$}} & \multirow{2}{*}{$\begin{array}{c}\text { Head \& } \\
\text { body } \\
(\mathrm{cm})\end{array}$} & \multirow{2}{*}{$\begin{array}{c}\text { Body } \\
\text { wt. } \\
\text { (kg) }\end{array}$} & \multicolumn{2}{|c|}{ Heart wt. } & \multirow{2}{*}{$\begin{array}{l}\text { Heart/ } \\
\text { body wt. } \\
\text { ratio }\end{array}$} & \multirow[b]{2}{*}{$\begin{array}{l}\text { d } \\
\dot{0} \\
z\end{array}$} \\
\hline & & & & & & $\begin{array}{c}\text { Absolute } \\
(\mathrm{kg})\end{array}$ & Relative & & \\
\hline 1 & Plakat & - & 1 & 132 & 71 & 0.660 & 0.929 & $1 / 107$ & $\Xi$ \\
\hline 2 & Pud & 1 & 1 & - & 318 & 1.800 & 0.566 & $1 / 176$ & $\stackrel{\gamma}{\varnothing}$ \\
\hline 3 & Pug & 6 & 2 & 280 & - & 3.650 & - & - & \\
\hline 4 & Plater ${ }^{1}$ & 7 & 3 & 228 & 530 & 2.450 & 0.462 & $1: 216$ & \\
\hline 5 & Pustelnik: & 8 & 5 & 269 & 630 & 3.100 & 0.492 & 1203 & \pm \\
\hline 6 & Punkt 1, 2 & 10 & 7 & - & 470 & 2.300 & 0.489 & $1 / 204$ & 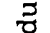 \\
\hline 7 & Stor-per & 11 & 6 & 255 & 580 & 3.350 & 0.577 & $1 / 173$ & 4 \\
\hline 8 & Plamiec & 14 & 5 & 262 & - & 3.150 & - & - & \\
\hline 9 & Plato & 17 & 4 & - & 750 & 3.400 & 0.453 & 1,220 & \\
\hline \multicolumn{2}{|r|}{ Avg. $(3-9)$} & & & & & 3.057 & 0.495 & $1 / 204$ & \\
\hline
\end{tabular}

1) Body wt. = weighed in the parts; ${ }^{2}$ ) Measurements by Dr. J. Ka l uz niacki.

The absolute weight of the heart of adult male bisons was from 2.300 to $3.600 \mathrm{~kg}$, mean $3.057 \mathrm{~kg}(\mathrm{n}=7)$. This corresponds to $0.58 \%-$ $0.45 \%$ of body weight, or $1 / 173-1 / 220$ of the weight of the whole animal (Table 3).

\subsection{Pars atrialis}

Atrium dextrum. Pars sinusalis of the right atrium is surrounded by numerous circular fibers of the myocardium (Fig. 6-30). Only in the posterior part, on the lateral wall are the fibers rather scarce. In adult animals the perimeter of atrium dextrum ${ }^{4}$ ) was $15.5-18.3 \mathrm{~cm}$ in the males and $15.0-18.0 \mathrm{~cm}$ in the females.

Several large veins open into the right atrium: $v$. cava cranialis, $v$. cava caudalis, sinus coronarius and $v$. azygos dextra. In adult spec-

4) Measured from the left atrium along its right wall and to the distinct border of the right auricle. 
imens the orifice of $v$. cava cranialis (Phot. 5, 6, Fig. 6-19) had a diameter of $38.8-46.1 \mathrm{~mm}$ in males and $39.4-41.0 \mathrm{~mm}$ in females. Its terminal part close to the orifice leading into the right atrium was covered by fibers of myocardium. V. cava caudalis (Phot. 6, 7, 8, Fig. 6 -21) at the level of the posterior heart border had the following diameters: $35.6-41.3 \mathrm{~mm}$ in adult males and $40.4-47.0 \mathrm{~mm}$ in adult females: It indicates that in the males $v$. cava cran. was larger or equal to $v$. cava caud. Only in one adult were the relations similar to those observed in females, namely $v$. cava cran. was slightly less developed than $v$. cava caud.

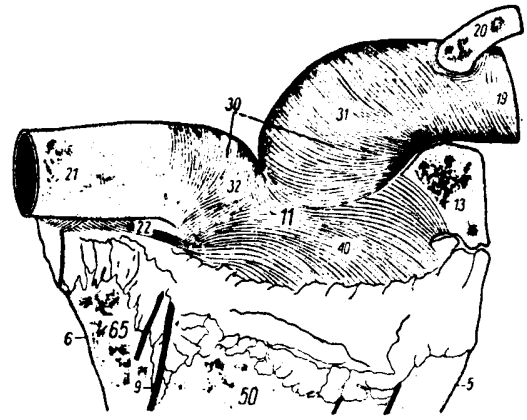

Fig. 6. External morphology of the right atrium of the bison heart; right view.

Sinus coronarius (Fig. 6-22) originates at the level of the posterior heart border from the merging of $v$. cordis magna (Fig. 18A-23) and $v$. azygos sin. (Phot. 5, 8,--24). This vessel goes anteriorly in the coronary groove and opens into the right atrium. In adult animals the diameter of coronary sinus at the orifice was aproximately $2 \mathrm{~cm}$. $V$. cordis media (Fig. 8-25) opens into the terminal part of this sinus. Only in one case $(2.8 \%)$ it was opening directly into the right atrium.

On the outside the coronary sinus is covered by circular and slightly oblique fibers of myocardium (Fig. 6-22). However, at the orifice of this vessel there are only longitudinal fibers which spread radially. They are derived from the wall of the right atrium. Myocardium surrounds also the terminal parts of the vessels forming the coronary sinus. In adult individuals myocardium was covering about $8 \mathrm{~cm}$ of $v$. azygos sinistra and about $3.5 \mathrm{~cm}$ of $v$. cordis magna.

Auricula dextra (Phot. 5, 6, 7, Fig. 6-13) lies at the anterior border of the heart and its free sharp apex (in adult animals $4.0-6.5 \mathrm{~cm}$ long) is directed left being adjacent to the pulmonary artery. The upper border of the auricle borders with $v$. cava cranialis and truncus brachiocephalicus com. It is transverse to the long axis of the heart. The ventral border of the right auricle goes obliquely left and dorsally to the level of the coronary groove. It has numerous variable notches. In adult 
individuals the right auricle had the following dimensions: height, $7.3-10.0 \mathrm{~cm}$ in males and $8.5-9.2 \mathrm{~cm}$ in females; perimeter, 14.5$15.5 \mathrm{~cm}$ and $14.0-14.2 \mathrm{~cm}$, respectively.

Vv. pulmonales (Phot. 8, Fig. 7-26) open into atrium sinistrum (Phot. 8, Fig. 7-12) through three sinuses: right, left and caudal. All sinuses are covered by well prononced myocardium with multi-directional fibers, which covers also the proximal parts of $v v$. pulmonales (Fig. 7).

Sinus dexter (Fig. 7-28) runs on the dorsal surface of the right auricle and the right branch of the pulmonary artery is adjacent to its dorsal wall. Two veins from the right lung which drain blood from its apical and cardiac lobes go into the right sinus.

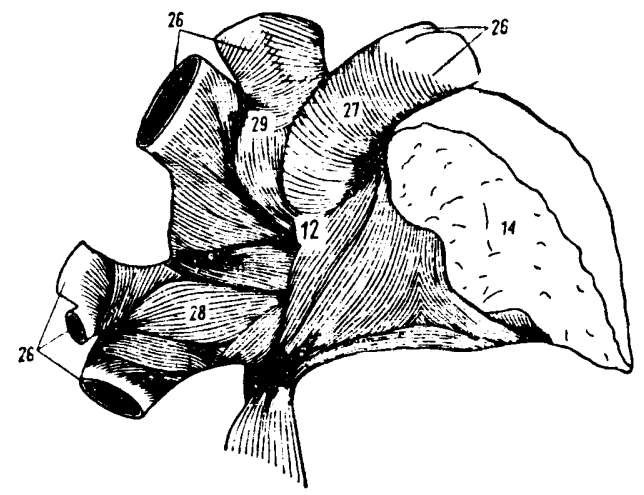

Fig. 7. External morphology of the left atrium of the bison heart; anterio-dorsal view.

Sinus sinister (Fig. 7-27) is least developed of the above mentioned three sinuses. It originates by the merging of vein branches which drain blood from the apical and cardiac lobes of the left lung. This sinus turns right, crosses $v$. azygos dextra from the top and opens into the dorsal wall of the left atrium.

Variation. In 4 cases $(16.6 \%)$ the left sinus was ending on the lateral and in 2 cases $(8.3 \%)$ on the dorso-lateral wall of the left atrium.

Sinus caudalis (Fig. 7-29) is best developed of the left atrium sinuses. It is formed by two large veins which drain blood from both diaphragmatic lobes and from the intermediate lobe of the lungs. This sinus opens into the dorso-caudal wall of the atrium. The circumference of the left atrium ${ }^{5}$ ) was $16.0-19.0 \mathrm{~cm}$ in adult males and $10.5-17.0$ $\mathrm{cm}$ in adult females.

Auricula sinistra (Phot. 5, 8, Fig. 7-14) is approximately triangleshaped. Its apex is on the level of the coronary groove and the apex

$\left.{ }^{5}\right)$ Measured from the orifice of $v$. cava caudalis to the apex of the left auricle. 
is directed dorsally. The ventral border of the left auricle is strongly notched. There is a considerable individual variation in the shape of the notches and therefore they are hard to describe.

In adult individuals the auricle had the following dimensions: height, $8.5-11.8 \mathrm{~cm}$ in males and $6.5-10.8 \mathrm{~cm}$ in females; circumference, $13.0-19.4 \mathrm{~cm}$ and $12.0-15.5 \mathrm{~cm}$, respectively. The left auricle was usually larger than the right. However, in 5 cases $(14.3 \%)$ it was slightly smaller.

\subsection{Pars ventricularis}

Facies dextra ( $f$. atrialis $\left.{ }^{6}\right)$ - FP; Phot. 6) is formed mainly by the wall of the right ventricle, while the wall of the left ventricle forms only a small part of it. On the right surface there is the right longitudinal groove. The anterior part of the right surface is strongly convex.

Facies sinistra (f. auricularis - FP; Phot. 5) is formed predominantly by the wall of the left ventricle. The right ventricle forms only its anterio-lateral part. The left longitudinal groove lies on this surface.

Margo cranialis ( $m$. acutus - FP; Phot. 5, 6-5) is strongly convex, especially in adult individuals. It has a distinct incision (Phot. 5, 6) at the connection of the walls of the right and the left ventricle.

Margo caudalis ( $m$. obtusus - FP; Phot. 5, 6-6) is slightly convex in its dorsal part and concave in its ventral part, close to the heart apex. In five cases $(14.3 \%)$ its course was resembling a straight line. Margo caudalis is much shorter than margo cranialis (Table 2).

In adult individuals both borders meet at the heart apex forming an angle $68^{\circ}-81^{\circ}$ in $0^{\top} 0^{\top}$ and $60^{\circ}-82^{\circ}$ in $ᄋ$ ㅇ. In young animals, between birth and maturity, this angle had values within the same range.

Sulcus coronarius (Phot. 5 to 8, Fig. 8-7) lies between atrium and ventricles. Usually a large amount of fat is accumulated in this sulcus area beneath pericardium.

Sulcus longitudinalis sinister (s. interventricularis paraconalis - FP; Phot. 5 to $7-8$ ) begins at the coronary groove between the pulmonary artery and the left auricle and lies on the left surface of the heart being nearly parallel to its posterior border. It crosses the anterior border on the level of the described incisura, goes across the left heart surface and joins the right longitudinal groove. In the left longitudinal groove there are blood vessels and adipose tissue beneath pericardium. The fat is especially abundant at the beginning of this groove.

${ }^{6}$ ) In this work new anatomic terms proposed by F. Preus (1956) for the description of animal heart will be given in addition to the terms hitherto used. For clarity, the former terms will be marked-FP. 
Sulcus longitudinalis dexter (s. interventricularis subsinosus - FP; Phot. 6, Fig. 8-9) originates on the level of ostium $v$. cavae caudalis. It goes from the coronary groove toward the heart apex, first straight but later forming an arch; its convexity facing posterior and eventually merging with the left longitudinal groove. Adipose tissue is found only at the beginning of the right longitudinal groove, around the blood vessels.

Variation. In the studied hearts the right longitudinal groove was very variable. In four cases $(11.4 \%)$ it was straight or nearly straight over its whole length. In four other cases $(11.4 \%)$ the groove was reaching only half of the right ventricle height, and below the right surface of the heart was smooth. The blood vessels usually located in the right longitudinal groove were below a thin layer of myocardium.

Sulcus longitudinalis accessorius (s. marginis obtusi - FP; Phot. 5, $8,10)$ begins at the coronary groove, usually at the level of the posterior heart border. It goes first along this border and then on the left heart surface down to the apex. Along this whole groove fat is deposited beneath the pericardium.

Variants. In the European bison there is considerable variation in the course of the intermediate groove. In 11 cases $(31.4 \%)$ it began at the level of the left auricle apex and was located exclusively on the left heart surface. In 8 cases $(22.8 \%)$ the intermediate groove did not reach the apex but ended in the middle of the left ventricle height.

In two cases $(5.7 \%)$ the intermediate groove was observed on the wall of the right ventricle. It was beginning at the coronary groove in the vicinity of the anterior border, between the right auricle and the right atrium. Then it was going down the anterior border of the heart nearly reaching the apex of the right ventricle.

\section{Internal Morphology of the Heart}

\subsection{The Right Atrium}

Atrium dextrum (Fig. 8, 12-11) is composed of two parts, pars sinusalis and pars propria atrii. They are divided by the circular crista terminalis on the internal wall of atrium (Fig. 8-33).

Pars sinusalis (Fig. 8-30) occupies the dorsal part of the right atrium and large vein-vessels open into it. In the European bison, similarly to other ruminants, pars sinusalis is composed of two regions: regio cranio-dorsalis and regio caudalis. These regions are quite distinctly separated by tuberculum intervenosum (s. Loweri) (Fig. 8, 12-34). This intervenous crest is formed by a strong bundle of myocardium fibers and in adult animals it can be as high as $5-7 \mathrm{~mm}$. 
Regio craniodorsalis (Fig. 8, 12-31) of the above mentioned pars sinusalis has a shape of a tube bent dorsal and widened at the end. Ostium $v$. cavae cranialis (Fig. $8,12-35$ ) is on its anterior wall and v. azygos dextra (Fig. 6-20) opens on its dorsal wall. From four to eight $v v$. cordis minimae which drain the blood from the walls of the right atrium also open in this region. Their openings are on the anteriolateral wall.

Regio caudalis (Fig. 8, 12-32) of pars sinusalis is smaller then the former region and is not so distinctly separated from the contours of the right atrium. It is adjacent to septum interatriale. Ostium $v$. cavae caudalis (Fig. 8, 12-37) is on the posterior wall of this region and sinus coronarius (Fig. 8, 12-38) opens below. In the majority of the studied hearts lamina valvuloidea - Ž e d e n ov (1961) (Fig. 8, 12-39) was present between these openings. In adult animals it was $1-6 \mathrm{~mm}$ long. It was partially covering ostium sinus coronarii. In 9 cases this lamina was absent.

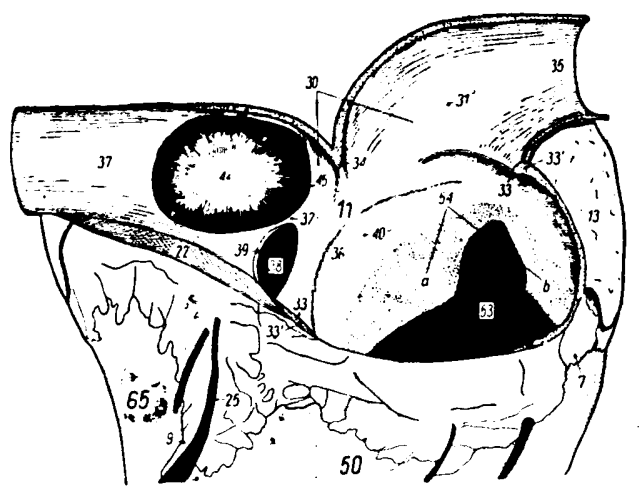

Fig. 8. Internal morphology of the left heart atrium of the bison; right view.

Pars propria atrii (Fig. 8, 12-40) is a ventral region of the right atrium. It is separated from pars sinusalis by about $1 \mathrm{~cm}$ wide fasc. terminalis (Fig. 8-33') a circular bundle in the wall of the atrium. This bundle runs obliquelly from the dorsal wall of the right auricle in posterio-ventral direction on the lateral wall of the right atrium. It lays below ostium sinus coronarii and merges with septum interatriale.

A proiruberance of the internal wall of the atrium, crista terminalis is forred along the course of the above described muscular bundle. On the lateral wall of pars propria atrii there are from 2 to 7 distinctly developed $\mathrm{mm}$. pectinati (Phot. 12, Fig. 12-42). They usually spread fan-like posterior and anterior, from crista terminalis toward the coro- 
nary groove. One of these $\mathrm{mm}$. pectinati is better developed and crosses into the right auricle. In 3 cases $(8.6 \%)$ this better developed $m$. pectinatus was not uniform but divided into several bundles.

Auricula dextra is a part of pars propria atrii. Its internal walls are covered with numerous $\mathrm{mm}$. pectinati. Their occurence and course are very variable but they can be divided into two groups. The first group is formed by $3-7$ weak $\mathrm{mm}$. pectinati (Phot. 9-43) which begin at the dorsal border, go toward the auricle apex slightly ventrally and gradually disappear on its anterior wall. Only in 2 cases $(5.7 \%)$ they had a slightly different course being directed exclusively ventrally. From 5 to $9 \mathrm{~mm}$. pectinati of the second group (Phot. 9-43') are stronger. They begin at the ventral border of the auricle run dorsally and slightly to the left and eventually disappear on its anterior wall.

The medial wall of the right atrium forms septum interatriale (Fig. $8,12-36)$. It has smooth walls. Near ostium $v$. cavae caudalis on the septal wall there is a large oval depression, the so called fossa ovalis (Fig. 8, 12-44). At the anterior it is surrounded by the high lying and strongly thickened margin, limbus fossae ovalis (Fig. 8, 12-45). Between this margin and the septal wall there is a strong infundibular depression directed toward the left atrium. The long axis of fossa ovalis has a anterio-caudal direction and in adult individuals is $3.8-4.6 \mathrm{~cm}$ long. The depth of this depression was from $2.5-3.8 \mathrm{~cm}$.

Foramen ovale was observed only in four young individuals (1-42 days old). However, one of the studied young animals (19 days old) already had closed foramen ovale.

\subsection{The Left Atrium}

Atrium sinistrum (Fig. 15-12) has smooth internal walls except the area of the left auricle. Three ostia of the sinuses which bring the blood from $v v$. pulmonales are seen in its dorsal part. Between the sinuses and across from the left atrioventricular orifice lie the left tuberculi intervenosi. The largest (Fig. 15-46) located at the orifices of sinus caudalis and sinus sinister is formed by a strong myocardium bundle, which in adult animals was $4.5-6 \mathrm{~mm}$ thick. The second tuberculum intervenosum (Fig. 15-46') lies on the border between orifices of sinus dexter and sinister and is about $5 \mathrm{~mm}$ high. The remaining tuberculum intervenosum lies between the ostia of sinus sinister and caudalis and can be up to $5 \mathrm{~mm}$ high. The above described tuberculi intervenosi, except the last one, are formed by strong fibers of myocardium. These fibers go from the left auricle on the dorsal wall of the discussed atrium, surround the ostia of the sinuses of the $v v$. pulmonales and 
spread radially on its right wall. The third tuberculum intervenosum is formed by the fibers of the myocardium which surround the caudal sinus.

In the left auricle $m m$. pectinati (Phot. 10) are better developed than in the right auricle. They can be divided into two distinct groups, 3-9 (in the average 5-6). Mm. pectinati of the first group (Phot. 10-43) begin at the dorsal border of the left auricle, run ventrally and gradually disappear in its lateral wall, without reaching the base of the auricle. The second group of $\mathrm{mm}$. pectinati (Phot. 10-48) begins at the base of the auricle. Individual muscular bundles run dorsal and interlace with $\mathrm{mm}$. pectinati of the former group and gradually disappear in the lateral wall of the auricle. There are $4-9$ (on the average 5-6) of these units.

The medial wall of the left atrium is formed by septum interatriale (Fig. 15-36). Part of this septum which originates at valvula foraminis ovalis, is rather distinctly convex in the direction of the left atrium. This is the thinnest part in septum interatriale. In this area the thickness of myocardium is only $1.0-1.5 \mathrm{~mm}$ in adult individuals.

In the middle and in the dorsal part of the left atrium wall a sickleshaped fold (Fig. 15-49) was observed in the majority of the studied hearts. It is a remnant of the free margin of the embryonal foramen ovale valve. This fold was usually connected with mostly single, rather strong chorda of tendinous character (Fig. 15-47), which was short, directed anterior and ending in septum interatriale.

Variation. In the European bison a variable number of chordae tendineae may branch from the above described sickle-shaped fold. In 8 cases $(22.8 \%)$ there were two chords and in 2 cases $(5.7 \%)$ - three. In three cases $(10.7 \%)$ the sickle-shaped fold was absent.

\subsection{The Atrio-ventricular Orifices and Their Valves}

Ostium atrioventriculare dextrum (Fig. 8, 9, 18A-53) is roughly oval shaped and wider at the anterior end. The long axis of this oval is directed from the posterior to the anterior and slightly obliquely left. In the hearts of adult individuals the perimeter of the right atrioventricular orifice was ranging from 22 to $27 \mathrm{~cm}$. The cusps of the tricuspid valve are attached to the fibrous ring of this orifice.

Valva atrioventricularis dextra s. tricuspidalis (Fig. 8, 9, 10, 12, -18A, -54 ) is composed of three cardinal cusps and accessory or intermediate cusps, which occur between the former ones and are very variable in both number and size (Table 4).

The tricuspid valve of the European bison can be classified into 5 types and many variants, depending on the occurence of intermediate 13 - Acta theriol. 
Table 4.

The number of cusps in the artio-ventricular velves of the bison heart.

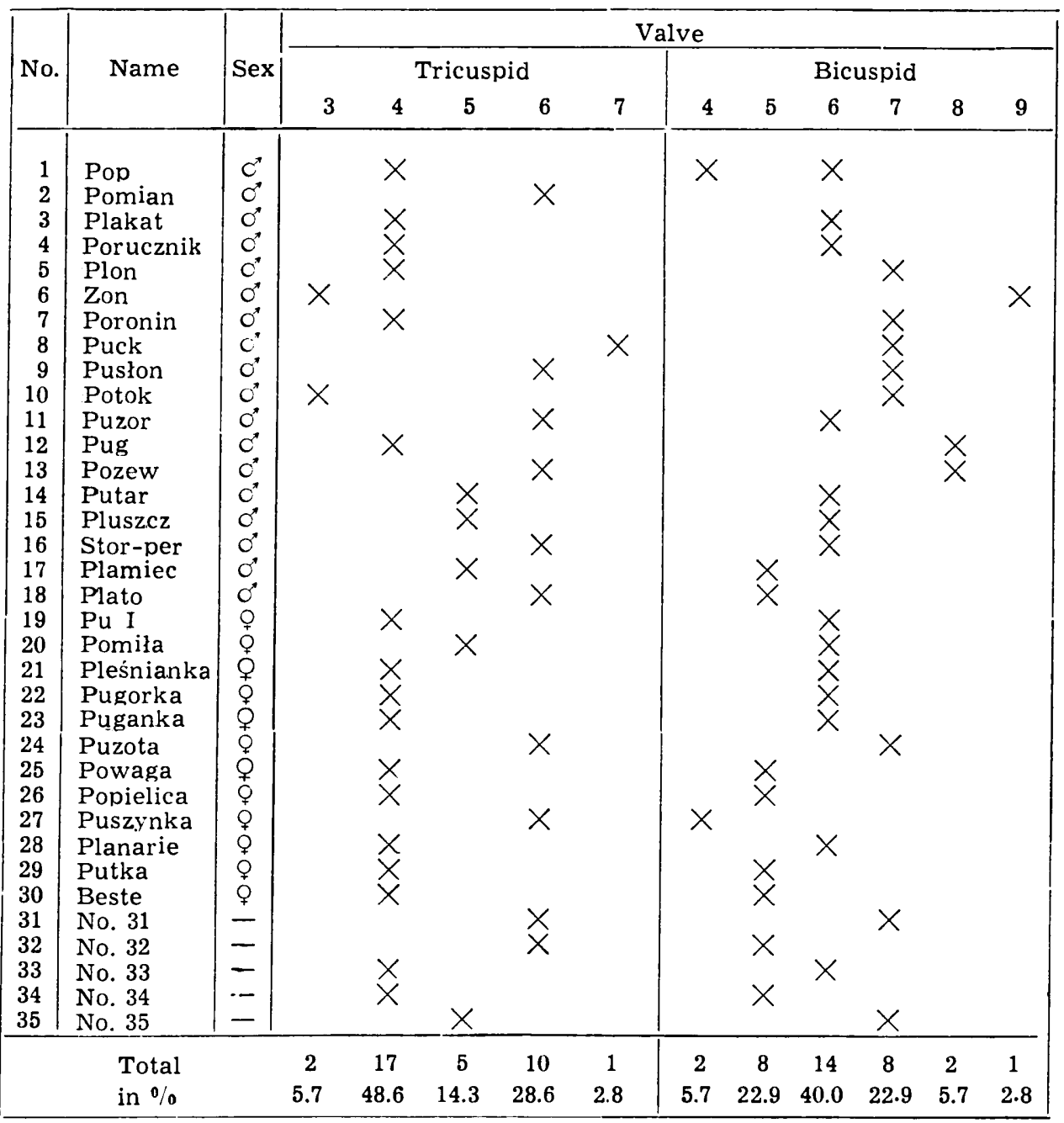

cups and size of cardinal cusps (Fig. 10). Cardinal cusps were named according to their location: septalis, cranialis and caudalis, while cuspi accessorii were named: cranialis, caudalis and lateralis ${ }^{7}$ ).

Cuspis septalis (Fig. 8, 9, 10,12,18A-54a) is short and wide with a semicircular free margin. Its length ${ }^{8}$ ) was variable, in adult animals from 2.0 to $3.6 \mathrm{~cm}$ and the width measured at the base was $5.7-$ $10.0 \mathrm{~cm}$.

i) Because of the occurence of numerous intermediate cusps in the bison the above mentioned names were introduced.

$\left.{ }^{8}\right)$ Measured from the base to the farthest point of the free margin. 
Cuspis cranialis (c. angularis - FP; Fig. 8, 9, 10, 12, - 54b) is triangular with truncated apex and variable height (cf. Fig. 10). In adult individuals it was $3.1-4.7 \mathrm{~cm}$ long and $3.6-6.8 \mathrm{~cm}$ broad at the base.

Cuspis caudalis (c. parietalis - FP; Fig. 9, 10, 12, 18A, - 54c) resembles a triangle with a broad base and truncated apex. Its length was $2.8-3.9 \mathrm{~cm}$ and the width at the base, $5.0-8.2 \mathrm{~cm}$.

Cuspis accessorius caudalis (Fig. 9, 10, 12, - 54d) was present in $91.4 \%$ of the studied bisons. It was located between cuspis caudalis and cuspis septalis. Its shape and size were variable (Fig. 10-d). Usually it was composed of one cusp, sometimes of two and exceptionally of three cusps. Cuspis accessorius caudalis was, in adult individuals, $1.2-4.0 \mathrm{~cm}$ long and $1.5-5.5 \mathrm{~cm}$ broad at its base.

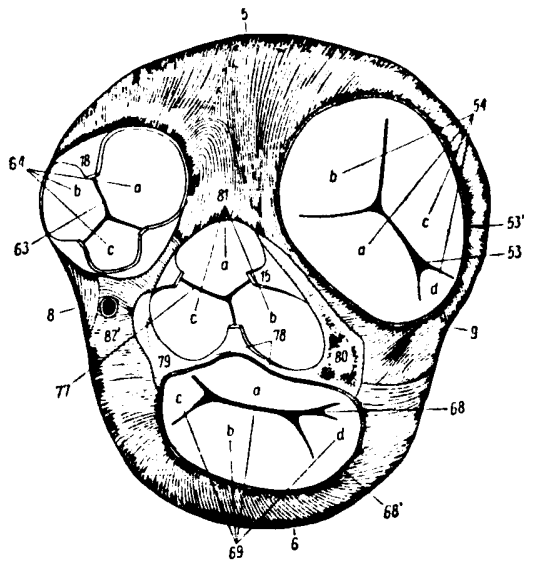

Fig. 9. The base of ventricles of the bison heart; dorsal view.

Cuspis accessorius lat. (Fig. 10-54f) lies between cuspis cranialis and cuspis caudalis and was observed in $31.4 \%$ of the animals. It is usually the weakest cusp of the tricuspid valve and only in one of 11 cases it was relatively well developed (Fig. $10-\mathrm{V}, \mathrm{f}$ ).

Cuspis accessorius cran. (Fig. 10, 54e) occurs relatively rarely (14.3\%) and lies between cuspis cranialis and cuspis septalis of the tricuspid valve. In adult animals it was $1.4-2.9 \mathrm{~cm}$ long and $1.0-1.5 \mathrm{~cm}$ broad (at the base).

Ostium atrioventriculare sin. (Fig. 9, 18A-68) is approximately oval shaped and its long axis is transverse to the long axis of the body (when the heart is in physiologic position). In adult individuals its circumference was ranging from 20.0 to $23.6 \mathrm{~cm}$. The cusps of the bicuspid valve are attached to the fibrous ring in the left atrioventricular orifice. 
Valva atrioventricularis sinistra s. bicuspidalis, s. mitralis (Fig. 9, 11, $15,18 \mathrm{~A}-69)$ is composed of two cardinal cusps: septalis and parietalis and two intermediate cusps: left and right. The intermediate cusps are
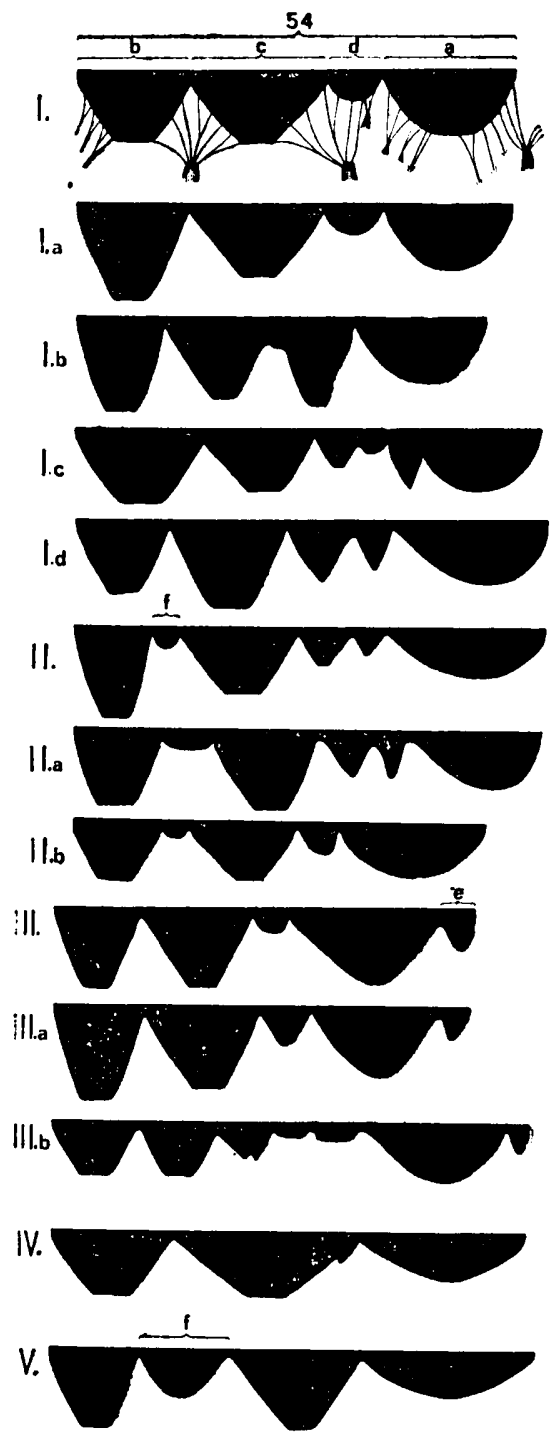

Fig. 10. Types of the tricuspid valve in the bison heart; drawn after cutting and spreading the valve.

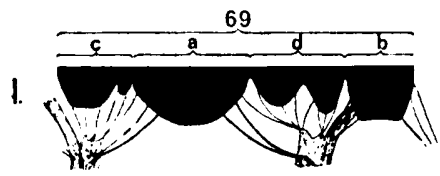

II.

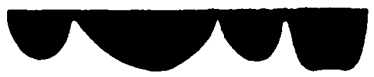

III.

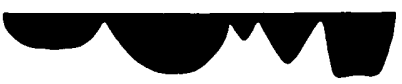

IV.

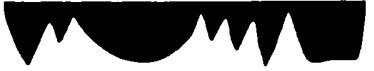

V.

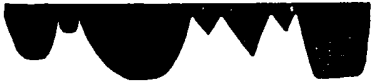

VI.

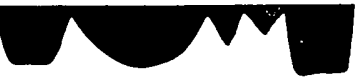

VII.
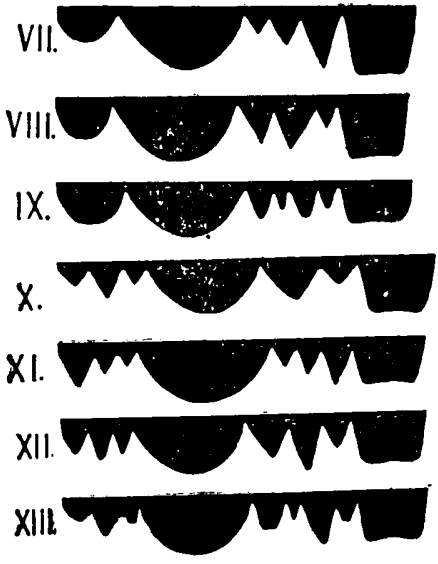

Fig. 11. Types of the bicuspid valve in bison heart; drawn after cutting and spreading the valve.

smaller than the cardinal cusps but occasionally they attain considerable dimensions. Thirteen types of the bicuspid valve (Fig. 11) were identified in the European bison, depending on their shape, size and the number of individual cusps (Table 4). 
Cuspis parietalis s. caudalis (Fig. 9, 11, 15, 18A-69b) is approximately square or rectangular. In adult animals it was $2.6-4.4 \mathrm{~cm}$ long and, at the base, $3.0-5.7 \mathrm{~cm}$ wide.

Cuspis septalis (Fig. 9, 11, 15, 18A-69a) is semicircular and the largest of the bicuspid valve cusps. I had variable length in relation to cuspis parietalis. In the studied individuals cuspis septalis and cuspis parietalis were usually of the same length. However, in some cases cuspis septalis was longer or shorter than cuspis parietalis (Fig. 11). In adult animals the above described cusp was $2.7-3.9 \mathrm{~cm}$ long and 6.8$8.3 \mathrm{~cm}$ broad at the base.

Cuspis accessorius sin. (Fig. 9, 11, 15, 18A-69c) had very variable shape. In 16 cases $(45.7 \%)$ it was uniform, in 14 cases $(40 \%)$ it was divided into two cusps and in the remaining 5 cases $(14.3 \%)$ - into three. Cuspis accessorius dexter (Fig. 9, 11, 15, 18A-69d) had also very variable shape and size. Most frequently (28 cases - $80 \%$ ) it was composed of 2 or 3 cusps and sometimes ( 7 cases $-20 \%$ ) of 1 or 4 . The size of both intermediate cusps and the remaining ones is compared in fig. 11.

\subsection{The Right Ventricle}

Ventriculus dexter (Fig. 9, 18 B to F-50) has a shape of irregular cavity with tapered apex. The ventricular septum forms its median wall. The right ventricle can be divided into ventriculus proprius or afflux route, between the atrio-ventricular orifice and the ventricle apex; and conus arteriosus dexter or reflux route, between the apex and the pulmonary orifice.

Ventriculus proprius (Fig. 12, 18 B, C-51) has numerous trabeculae carneae on the internal wall and between them shallow or deeper sulci and $\mathrm{mm}$. papillares with chordae tendineae and $\mathrm{mm}$. transversi.

Trabeculae carneae (Fig. 12-52) located on the lateral wall of the described ventriculus proprius, are very well pronounced. They are oblique and directed from the atrioventricular orifice toward the apex of the right ventricle $i$. e. ventrally and to the right. Specially well developed are chordae tendineae on the lateral wall below the tricuspid valve (Phot. 12; Fig. 18BC-52'). They are parallel to the long axis of the heart. Occasionally only their ends are attached to the wall and their middle parts are free. There were from 3 to 7 chordae tendineae and most frequently four.

On the ventricular septum chordae tendineae are less pronounced than on the lateral wall and the sulci between them are shallower and shorter. Trabeculae carneae are parallel to the long axis of the heart. 
M. papillaris cran. (m. p. magnus - FP; Phot. 12, Fig. 12, 18B, D55 ) is the largest, begins on the anterior wall of the right ventricle, is directed dorsally and ends with an apex (Fig. 13, 18B-55') composed of a variable number of cones, most frequently 2 or 3 . The muscle is broad, very flat and has an oval crossection. Its surfaces are smooth and only close to the base there were three quite pronounced sulci in the majority of animals. The dimensions of $m$. papillaris cranialis, similarly to those of the remaining muscles occuring in the right and the left ventricle, are presented in table 5.

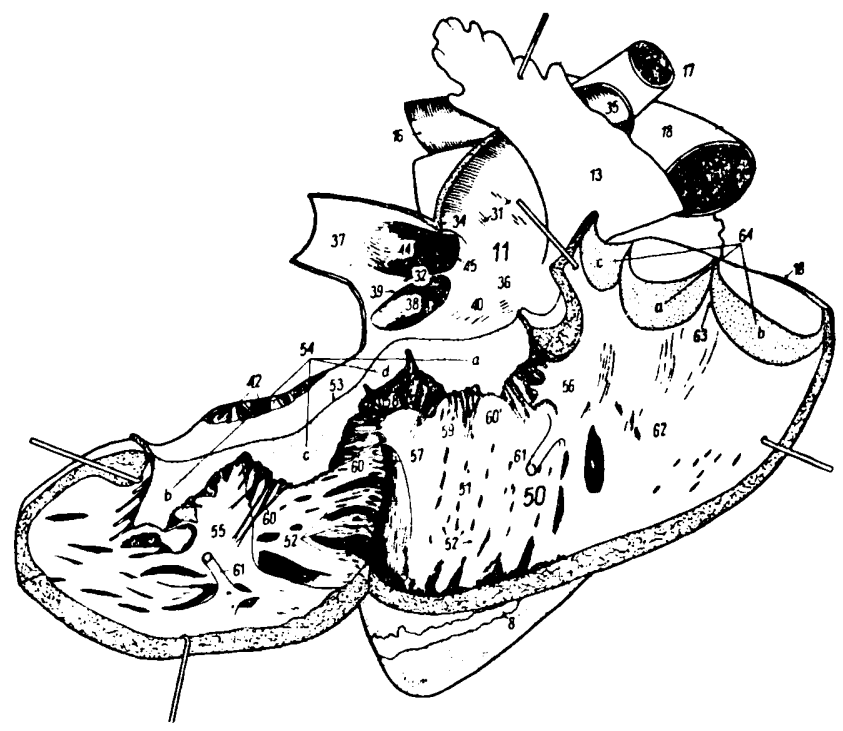

Fig. 12. The right ventricle of the bison heart; lateral wall incised and opened; anterior view.

Variants. In two cases $(5.7 \%) m$. papillaris cranialis was cylinder-shaped and its apex had only one cone (Fig. 13c). In two other cases $(5.7 \%)$ it had a split apex (Fig. $13 \mathrm{~d}$, e) and in one case $(2.9 \%)$ its apex ended with 4 cones (Fig. 13f).

Chordae tendineae (Fig. 12-60) of $m$. papillaris cranialis were 8-17 in number and on the average, 10-11. Almost all were beginning at its apex and in most cases only one or two were beginning a little below in the depression beneath the apex.

Chordae tendineae of $m$. papillaris cranialis are attached to both cuspis parietales; 2-8 (mean 4-5) to cuspis cranialis, and 3-10 (mean 6 -7) to cuspis caudalis. The latter ones were stronger. Whenever cuspis accessorius lateralis is present in the tricuspid valve, the described muscle is connected with this cusp by $1-3$ tendinous chords. 
M. papillaris subarteriosus (Fig. 12, 18-56) lies on the dorsal part of the ventricular septum, in adult animals approximately $4.5 \mathrm{~cm}$ from ostium a. pulmonalis. This is usually the weakest $m$. papillaris of the right ventricle although sometimes it is only slightly smaller than $m$. papillaris caudalis dexter. The apex of $m$. papillaris subarteriosus

Table 5.

Measurement of $\mathrm{mm}$. papillares of the European bison heart (in $\mathrm{mm}$ ).

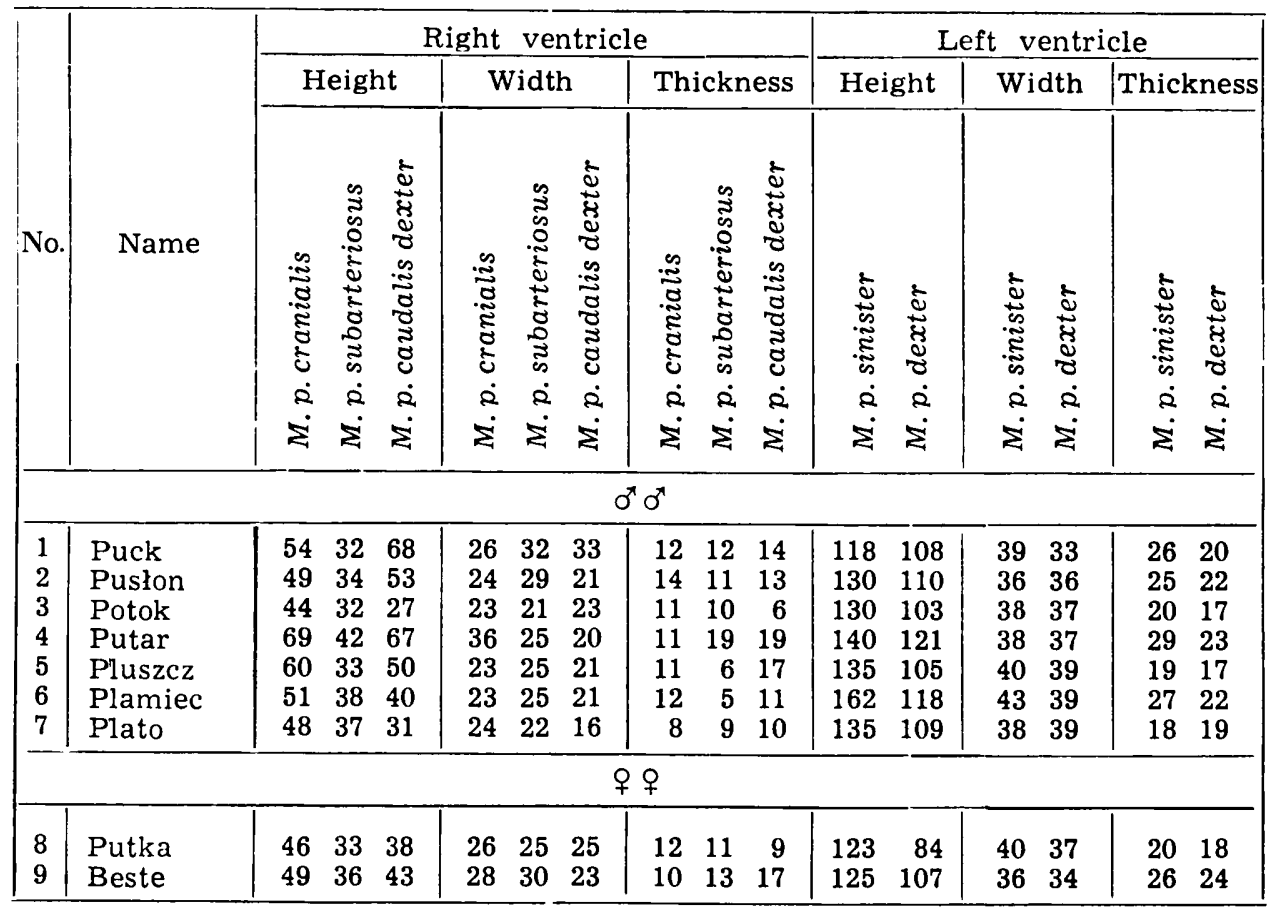

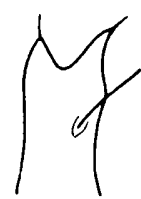

a

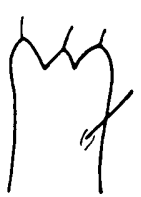

$b$

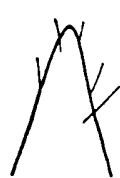

c

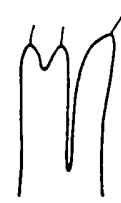

$d$

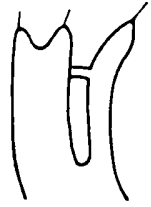

e

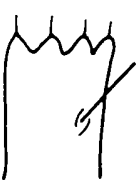

$f$

Fig. 13. The variants of the apex of $m$. papillaris cranialis in the bison.

ends usually with a single cone about $5 \mathrm{~mm}$ long. Surfaces of the described muscle are smooth.

Variation. In 6 cases $(17.1 \%)$ the left border of the apex of m. papillaris subarteriosus was elongated dorsally into trabecula carnea. It was ending on the ventricular septum beneath the right atrio-ventri- 
cular orifice. In 2 cases $(5.7 \%)$ the apex of the described muscle was divided into two cones.

Chordae tendineae of $m$. papillaris subarteriosus were connected with cuspis cranialis and cuspis septalis of the tricuspid valve. There were from 4 to 13 chords but on the average, 9-10. They extend not only from the apex of the described muscle but also from its right surface and sometimes from $m$. transversus cordis.

Cuspis cranialis receives $2-8$ and on the average $4-5$ tendinous chords while cuspis septalis receives $1-8$, on the average $4-5$. M. papillaris subarteriosus can also send $2-3$ chordae tendineae to the irregularly occuring cuspis accessorius cranialis.

M. papillaris caudalis dexter (Fig. 12, 18D-57) extends from the ventricular septum close to its caudal part merging into the lateral wall. Its bluntly ending apex is usually cylinder-shaped. The height of the apex is variable and can be up to $1.8 \mathrm{~cm}$.
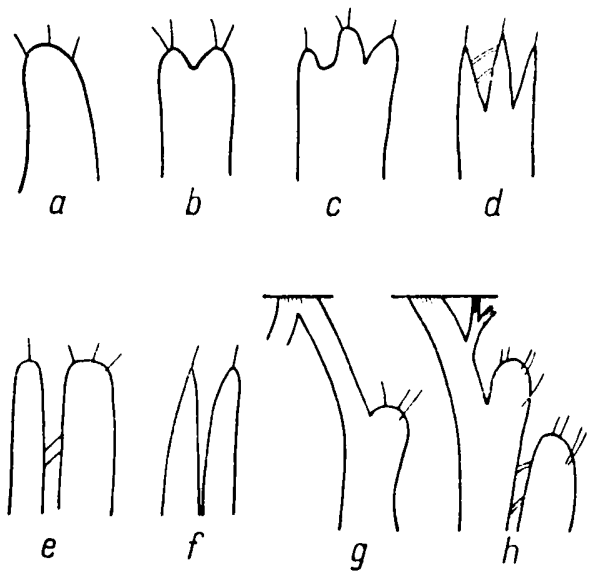

Fig. 14. The variants of the apex of $m$. papillaris caudalis dexter in the bison.

Variation. The variability of the structure of $m$. papillaris caudalis dexter results from the division of the apex or from the occurrence of an additional trabecula carnea. The apex of this muscle was divided into 2 or 3 cones in 7 cases $(23 \%)$ (Fig. 14 b, c, d) and in 4 cases $(11.4 \%$ ) it was double (Fig. 14e, f, h). In two cases $(5.7 \%)$ the quite strong trabecula carnea (Fig. 14, g, h) was extending from the apex of $m$. papillaris caudalis dexter and ending on the lateral wall of the ventricle close to the right atrio-ventricular orifice.

Chordae tendinae of $m$. papillaris caudalis dexter were from 4 to 15 in number (on the average 7-8) and were ending in cuspis caudalis, 
cuspis septalis and cuspis accessorius caudalis of the tricuspid valve. Cuspis caudalis receives 1-6 chordae (average 3-4), cuspis septalis 1-6 (average 2-3) and cuspis accessorius caudalis 1-8 (average 2-3). Variation. In 6 cases $(17.1 \%) m$. papillaris caudalis dexter did not send any chordae tendineae to cuspis septalis of the tricuspid valve.

$M$. papillaris accessorius (Fig. 12-58) was present in $60.6 \%$ of the studied material (20 cases). It is located on the ventricular septum, posterio-dorsally to $m$. papillaris caudalis dexter. It was cone-shaped with a blunt apex. From 1 to 7 (average 2-3) chordae tendineae of this muscle were usually connected with cuspis accessorius caudalis.

Variation. In two cases $m$. papillaris accessorius was double. In 3 cases it was sending $1-3$ chordae tendineae also to cuspis septalis and in 2 cases also 3 chords to cuspis caudalis.

$M m$. papillares proprii septales (Fig. 12-59) were present in the hearts of 11 bisons $(33.3 \%$ of the studied material). They were small, cone shaped and lay on the ventricular septum anterior from $m$. $p a-$ pillaris caudalis dexter. Their number was variable. Two to four chordae tendineae of these muscles were ending in cuspis septalis of the tricuspid valve. In addition to the above mentioned chordae tendineae of $\mathrm{mm}$. papillares proprii septales, cuspis septalis of the tricuspid valve was in 20 cases $(60.6 \%)$ connected also with $2-9$ (average $4-5$ ) chords extending from the ventricular septum (Fig. 12, $-60^{\prime}$ ). Only in one of the studied hearts $(3.3 \%) \mathrm{mm}$. papillares proprii septales and the above described independent chordae tendineae were not present.

$M m$. papillares proprii laterales (one or two) were present only in two cases $(5.7 \%)$. They were on the lateral wall of the right ventricle posterio-ventrally to $m$. papillaris cranialis. Each of these muscles was cylinder shaped with the apex ending in a single cone. One or two chordae tendineae were connecting these muscles with cuspis caudalis of the tricuspid valve.

$M m$. transversi were represented by one strong and several weaker muscles. The relatively stronger $m$. transversus (Fig. 12, 18B, C, -61) goes from the ventricular septum to the lateral wall of the right ventricle on which it ends below $m$. papillaris cranialis. It is nearly circular in the crossection with a diameter from 7.5-11 $\mathrm{mm}$ and a length from 4.5 to $6.5 \mathrm{~mm}$ (in adult animals). It ends on the lateral wall of the right ventricle often forming $3-4$ strong branches. Occasionally it receives also several thin branches from the ventricular septum. In four cases $(11.4 \%)$ instead of the above described strong $m$. transversus there were two weaker muscles.

The remaining 2-6 $\mathrm{mm}$. transversi of the right ventricle are usually short, threadlike and strongly tendinous. They connect the ventricular 
septum with $m$. papillaris caudalis dexter. In 8 cases $(22.8 \%)$ some of the mentioned $m$. transversi usually tendinous, had definitely musciular character and their diameter was up to $2 \mathrm{~mm}$. In 3 cases $(8.5 \%)$ the small threadlike $\mathrm{mm}$. transversi were found also near the apex of the right ventricle. They were beginning on the ventricular septum and ending on the lateral wall.

Conus arteriosus dexter (Fig. 12, 18B, C, D, -62) functioning as reflux route is not very distinct from the remaining part of the right ventricle. Dorsally, conus reaches higher than ventriculus proprius and consequently the ratio of lenghts of the afflux and reflux routes is $2: 3$.

Table 6.

The measurements of valvulae semilunares of the arterial valves (in $\mathrm{mm}$ )..

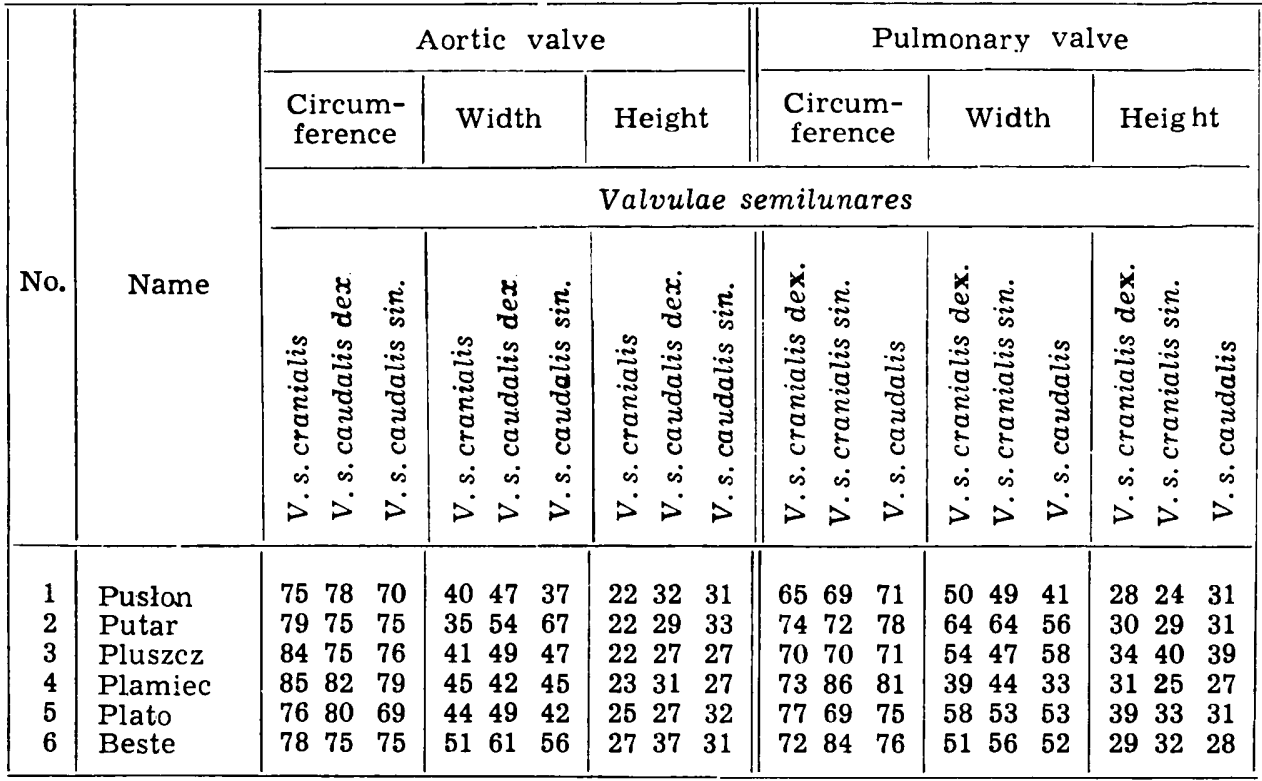

The internal walls of conus arteriosus dexter are smooth. Only on the level of the left longitudinal groove in the ventral part of the ventricle there are strong chordae tendineae extending from the ventricular septum to the lateral wall.

On the dorsal wall of the described cone lies ostium arteriae pulmonalis (Fig. 9, 12, 18A, -63). In adult individuals its perimeter was from 12.5 to $18.5 \mathrm{~cm}$.

In the pulmonary orifice there is valva arteriae pulmonalis ( $v$. trunci pulmonalis - FP; Fig. 9, 12, 18A -64) composed of three valvulae semilunares. Two of these, right (a) and left (b) lie anteriorly and one 
(c) posteriorly. The measurements of the length ${ }^{9}$ ), the width ${ }^{10}$ ) and the circumference of the free margin of valvulae semilunares of the pulmonary valve are given in table 6 .

The center of the free margin of almost every valvula has nodulus valvulae semilunaris (s. Arantii). In valvula semilunaris cranialis sinistra et caudalis these nodules have a shape of oblong trabecula and in valvula semilunaris cranialis dextra they looked like three "rods " lying transverse to the free margin.

Variation. In four cases $(11.4 \%)$ noduli of the valvulae semilunares were weakly pronounced and in 3 cases $(8.5 \%)$ they were absent on one valvula semilunaris of the pulmonary valve.

\subsection{The Left Ventricle}

Ventriculus sin. (Fig. 15, 18, B through to $\mathrm{G}-65$ ) is approximately cone-shaped. Its wall is two times thicker than the wall of the right

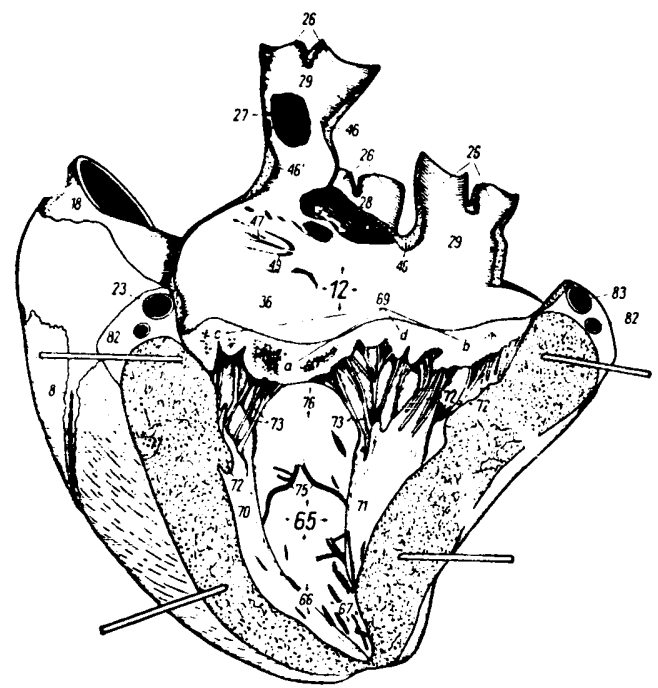

Fig. 15. The left atrium and the left ventricle of the bison heart; lateral wall incised and opened; posterior view.

ventricle (Table 7). The cavity of the left ventricle, similarly to that of the right one, is composed of ventriculus proprius or afflux route: from the left atrio-ventricular orifice to the ventricle apex and reflux route, or conus arteriosus sinister in which the blood flows from the ventricle apex to the aortic orifice.

\footnotetext{
9) Measured in the middle of the cusp, from the base to the free margin.

10) Measured after cutting the wall of the pulmonary artery, between the highest points of the insertion of valvula semilunaris of the valve.
} 
Ventriculus proprius (Fig. 15, -66) contains trabeculae carneae, $\mathrm{mm}$. papillares with chordae tendineae and $\mathrm{mm}$. transversi.

Trabeculae carneae are well developed especially on the level of the right longitudinal groove near the ventricle apex. They are parallel to the long axis of the heart and connect the ventricular septum with lateral wall. However, trabeculae carneae across from the left longitudinal groove are much less pronounced, low and broad with shallow sulci between them. On the lateral wall of the left ventricle near the atrio-ventricular orifice, below the bicuspid valve there are 3-4 strong large trabeculae carneae. They are parallel to the long axis of the heart and two of them (Fig. 15, 18B, C, -72) usually stem from the apexes of the papillary muscles. They will be described in more details in further sections of this work.

Table 7.

The thickness of the walls of the heart of the European bison (in $\mathrm{mm}$ ).

\begin{tabular}{|c|c|c|c|c|c|c|c|c|c|}
\hline \multirow[t]{2}{*}{ No. } & \multirow[t]{2}{*}{ Name } & \multirow{2}{*}{$\begin{array}{l}\text { Age } \\
\text { (years, } \\
\text { months) }\end{array}$} & \multicolumn{3}{|c|}{ Right ventricle } & \multicolumn{3}{|c|}{ Left ventricle } & \multirow{2}{*}{$\begin{array}{c}\begin{array}{c}\text { Ventricular } \\
\text { septum }\end{array} \\
1\end{array}$} \\
\hline & & & 1 & 2 & 3 & 1 & 2 & 3 & \\
\hline \multicolumn{10}{|c|}{$\sigma^{\prime} \sigma^{\circ}$} \\
\hline $\begin{array}{l}1 \\
2 \\
3 \\
4 \\
5 \\
6 \\
7 \\
8\end{array}$ & $\begin{array}{l}\text { Puck } \\
\text { Pusłon } \\
\text { Potok } \\
\text { Putar } \\
\text { Pluszcz } \\
\text { Stor-per } \\
\text { Plamiec } \\
\text { Plato }\end{array}$ & $\begin{array}{rr}4 & 1 \\
4 & 9 \\
4 & 10 \\
6 & 5 \\
10 & 5 \\
11 & 6 \\
14 & 5 \\
17 & 4\end{array}$ & $\begin{array}{l}20 \\
24 \\
18 \\
22 \\
19 \\
21 \\
26 \\
18\end{array}$ & $\begin{array}{l}16 \\
15 \\
14 \\
17 \\
14 \\
16 \\
22 \\
13\end{array}$ & $\begin{array}{l}3 \\
5 \\
4 \\
5 \\
4 \\
6 \\
6 \\
4\end{array}$ & $\begin{array}{l}40 \\
42 \\
39 \\
48 \\
38 \\
39 \\
46 \\
34\end{array}$ & $\begin{array}{l}27 \\
29 \\
26 \\
31 \\
30 \\
27 \\
32 \\
26\end{array}$ & $\begin{array}{l}3 \\
6 \\
3 \\
6 \\
5 \\
6 \\
5 \\
5\end{array}$ & $\begin{array}{l}32 \\
41 \\
30 \\
40 \\
37 \\
32 \\
41 \\
30\end{array}$ \\
\hline \multicolumn{10}{|c|}{ 우우 } \\
\hline $\begin{array}{r}9 \\
10\end{array}$ & $\begin{array}{l}\text { Putka } \\
\text { Beste }\end{array}$ & $\begin{array}{ll}20 & 4 \\
23 & 9\end{array}$ & $\begin{array}{l}18 \\
21\end{array}$ & $\begin{array}{l}12 \\
14\end{array}$ & - & $\begin{array}{l}43 \\
36\end{array}$ & $\begin{array}{l}24 \\
32\end{array}$ & - & $\begin{array}{l}34 \\
29\end{array}$ \\
\hline
\end{tabular}

1 - The thickest spot, 2 - In the center of ventricle height, 3 - On the apex.

M. papillaris sinister (m. p. subatrialis - FP; Fig. 15, 18B to G, -70) lies on the lateral wall of the left ventricle. It begins on the ventricle apex and is directed dorsally in accordance with the long axis of the heart. It is broadened at its dorsal part and ends with a short free apex (Fig. 18B, $-70^{\prime}$ ). On this apex there is a variable number of coni but most often 3 or 2 (Fig. 16). Only in one case $(2.8 \%)$ there were 4 coni. The surface of the described muscle is generally smooth. Only in its ventral part several (usually 3) short and narrow sulci can be observed.

In 27 cases $(77.1 \%)$ strong trabecula carnea (Phot. 13; Fig. 15, 16, 18 $B,-72)$ was extending from the posterior border of $m$. papillaris sini- 
ster. It was running on the posterior wall of the ventricle below cuspis parietalis of the bicuspid valve to the left atrio-ventricular orifice. Its terminal part was sometimes tendinous. Shallow longitudinal sulcus was often observed in the middle of the described trabecula.

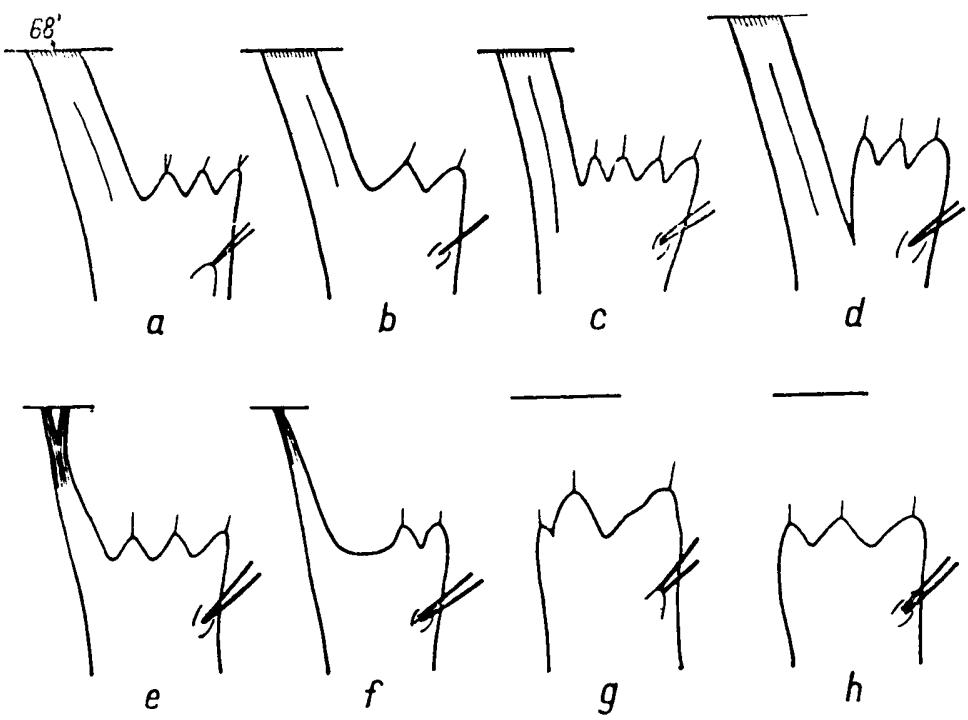

Fig. 16. The variants of the apex of $m$. papillaris sinister in the bison.

Variation. In two cases $(5.7 \%)$ trabecula carnea of $m$. papillaris sinister was extending not from the apex but from the lateral wall of the papillary muscle (Fig. 16d). In three cases $(8.6 \%) \mathrm{m}$. papillaris sinister was ending not with the trabecula but with a high conus which was forming a long and strong chorda tendinea (Fig. 16e, f). This chord had its insertion on the fibrous ring surrounding the left atrio-ventricular orifice. In five cases $(14.2 \%)$ the described muscle did not send any trabeculae or chordae tendineae toward the atrio-ventricular orifice (Fig. $16 \mathrm{~g}, \mathrm{~h}$ ). In these cases trabeculae carneae were present only on the posterior wall of the left ventricle.

M. papillaris sinister sends 7-16 (average 11) chordae tendineae (Fig. 15, -73) to cuspis septalis, cuspis accessorius sinister and cuspis parietalis of the bicuspid valve. The strongest chords (from 2 to 6 , average 3-4) are connected with cuspis septalis. They extend from the single cone and from the sub-apical groove of $m$. papillaris. Cuspis accessorius sinister is connected with 2-7 (average 4-5) tendinous chords of different size, depending on its dimensions. From 1 to 5 (mean: 3-4) chordae tendineae of average thickness extend to cuspis parietalis of the bicuspid valve. 
M. papillaris dexter (m. p. subauricularis - FP; Phot. 13; Fig. 15, $18 \mathrm{C}$ to $\mathrm{G},-71$ ) also lies on the lateral wall of the left ventricle. It is lower than $m$. papillaris sinister (Table 5). The described muscle begins near the left ventricle apex, is directed dorsally and ends with a short apex (Fig. 18C, $-71^{\prime}$ ), on which there are a variable number of coni; from 1 to 5 (Fig. 17). $M$. papillaris dexter has generally smooth surfaces except for its lower part where single long sulcus was observed in the majority of the studied hearts. Sometimes it had 1-2 additional shallow longitudinal grooves.

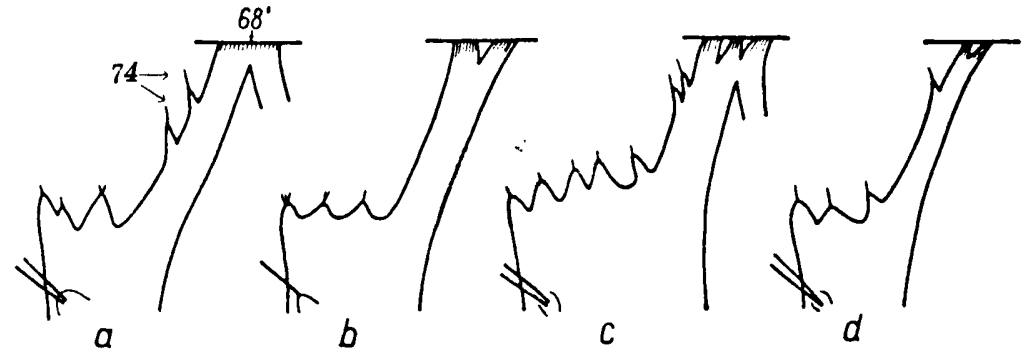

a

$b$
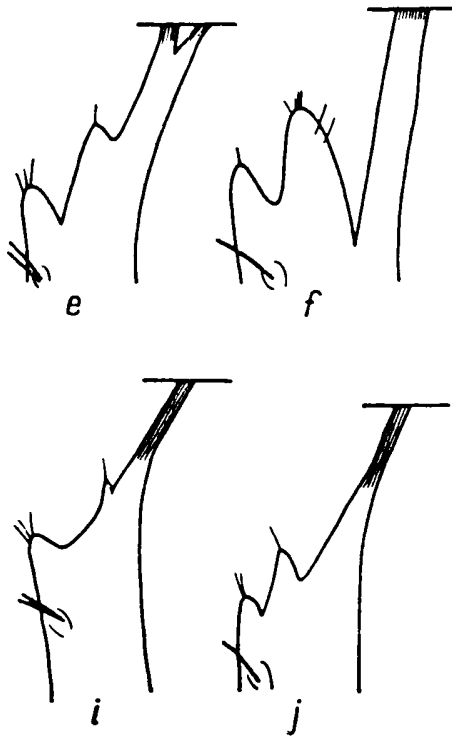

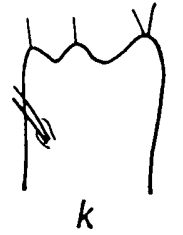

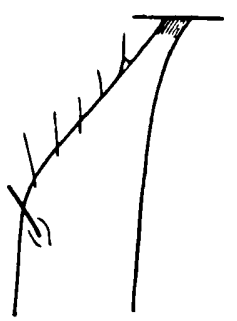

$h$

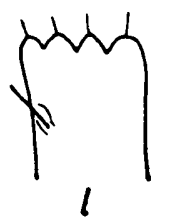

Fig. 17. The variants of the apex of $m$. papillaris dexter in the bison.

In 24 cases $(68.5 \%)$ the posterior border of $m$. papillaris dexter was elongated to form directly a strong trabecula carnea (Phot. 13; Fig. 15, $17,18 \mathrm{~B}, \mathrm{C},-72)$ which goes dorsally, is connected with the lateral wall of the ventricle and ends near the left atrio-ventricular orifice sometimes with a short and broad tendo. 
Variation. Quite frequently (in 9 cases, or $25.7 \%$ ) on the described muscle there was a high conus rather than trabecula. This conus was running into strong and long chorda tendinea ending on the fibrous ring surrounding the left atrio-ventricular orifice. This conus was in $\bar{j}$ cases extending from the posterior margo of the apex of $m$. papillaris dexter (Fig. 17i, j) and in the remaining 4 cases from the center of the apex (Fig. 17g).

In 2 cases $(5.7 \%) m$. papillaris dexter had neither trabecula nor high conus with the chord connected to the left atrio-ventricular orifice (Fig. $17 \mathrm{k}, 1)$. In 3 cases $(8.6 \%) m$. papillaris dexter was beginning, as usually, from the left ventricle apex but with two branches having a deep sulcus between them.

Chordae tendineae of $m$. papillaris dexter (7-15, average: 11) extend to cuspis septalis, cuspis parietalis and cuspis accessorius dexter of the bicuspid valve. Cuspis parietalis receives 2-4 (average 2-3) of the strongest chordae tendineae. They begin in the depression below the apex of $m$. papillaris dexter and on coni of this apex. Chordae tendineae connected with cuspis accessoriuc dexter (3-8, average 4-5) are of variable size. $M$. papillaris dexter sends $2-7$ and average $3-4$ chordae tendineae to cuspis parietalis of the bicuspid valve.

$M m$. papillares accessorii (Fig. 17, -74) were present in the left ventricle in 23 cases $(65.7 \%)$. They were extending from the above described trabecula carnea of $m$. papillaris dexter as small coni. Their chordae tendineae were ending on cuspis parietalis of the bicuspid valve, close to its base.

$M m$. transversi. In the left ventricle, unlike the right ventricle, there are only thin, strongly tendineous $\mathrm{mm}$. transversi (from 3 to 11 ). Their course and devision are very variable.

Two $\mathrm{mm}$. transversi (Fig. 15, - 75) were most stable and were found in almost all studied cases. They were extending from the central part of the ventricular septum often very close to each other and each was directed toward one $m$. papillaris. Thickness of these $\mathrm{mm}$. transversi was very variable, in adult individuals usually from $1.3-2 \mathrm{~mm}$; their length was approximately $5 \mathrm{~cm}$. The above described $\mathrm{mm}$. transversi were connected with the ventricular septum by several $(1-3)$ branches and before reaching their respective $m$. papillares were sometimes dividing into several branches.

The remaining $\mathrm{mm}$. transversi of the left ventricle differed very strongly from one individual to another. Their length, thickness and location were variable. In 3 cases $(9.7 \%)$ there were minute $\mathrm{mm}$. transversi connecting the ventricular septum with the lateral ventricle wall. 
Conus arteriosus sin. (Fig. 15, 18B, -76) is not very distinct from ventriculus proprius of the left ventricle. Its anterior wall is formed by the concave ventricular septum. The dorsal part of this septum is smooth and the ventral covered with not very pronounced trabeculae carneae. On the dorsal wall of conus arteriosus sinister there is the aortic orifice with a valve.
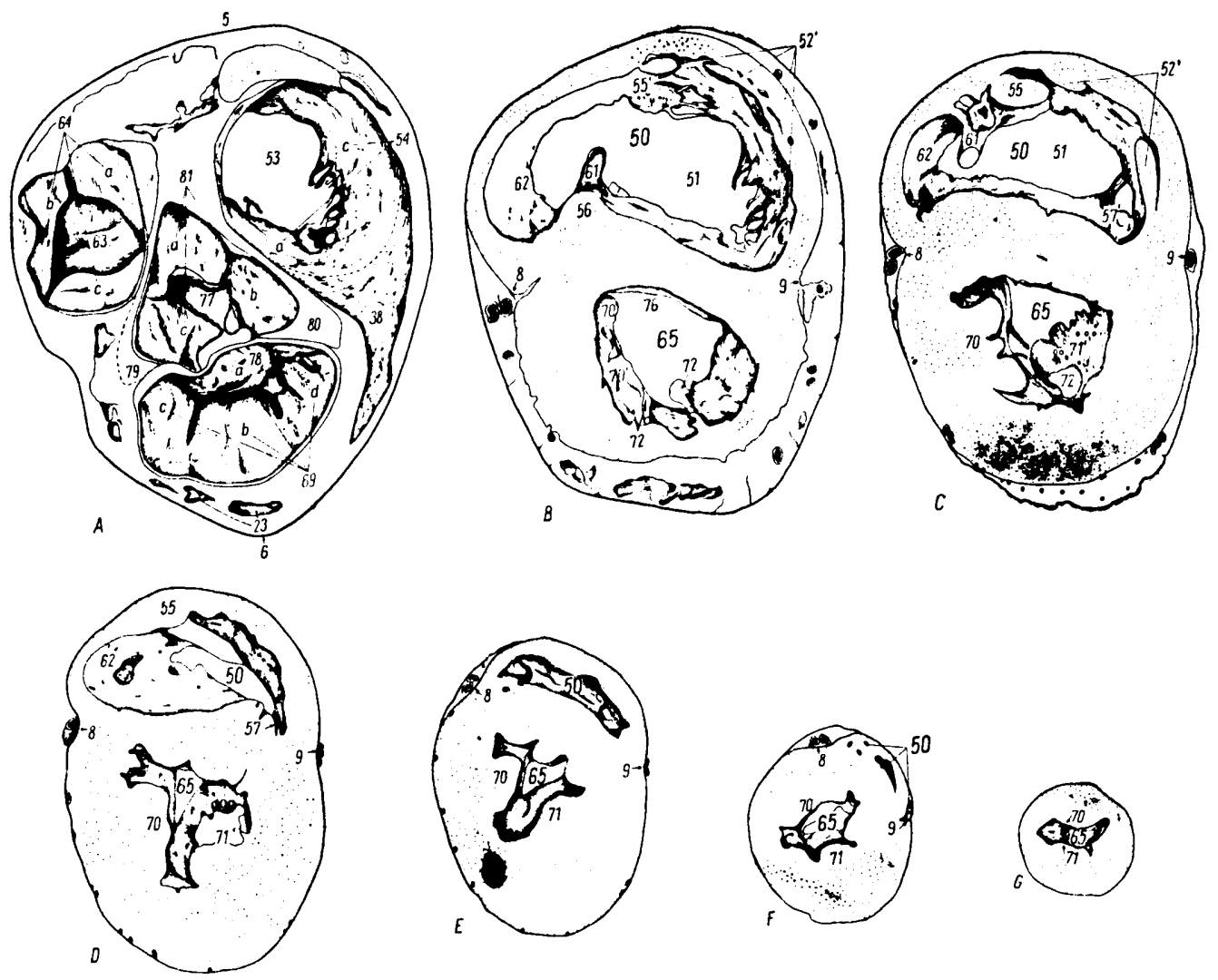

Fig. 18. Schemes of the crossections of the bison heart ( + , Putka, 20 years old); dorsal view of the sections.

Ostium aortae (Fig. 9, 18A, -77) of adult individuals had a perimeter of $11-15 \mathrm{~cm}$. It is located on the base of pars ventricularis of the heart between the left and the right atrio-ventricular orifices. The aortic orifice and the left atrio-ventricular orifice are separated only by rather strong, elastic membrana aorto-ventricularis terminalis (Fig. $9,18 \mathrm{~A},-78)$. It has insertions on both ossa cordis. At these insertions the internal wall of the left ventricle forms pronounced, cone-shaped eminences, which in adult animals were aprroximately $1.5 \mathrm{~cm}$ high. 
Valva aortae (Fig. 9, 18A, -81), similarly to the pulmonary valve is composed of three valvulae semilunares. However, in the aorta their position is reversed: there is one valvula cranialis (a) and two posterior ones, valvula caudalis dextra (b) and valvula caudalis sinistra (c). Their dimensions are given in table 6 .

Nodulus of valvulae semilunaris was observed on every valvulae of the aortic valve in almost all cases studied. These nodules were much thicker than in the pulmonary valve. In valvula semilunaris cranialis and in valvula semilunaris caudalis dextra this nodulus was resembling a longitudinal trabecula, while in valvula semilunaris caudalis sinistra it was oval shaped.

Variation. In 5 cases $(14.2 \%)$ noduli of valvulae semilunares were weakly pronounced. This was especially true about valvula semilunaris caudalis sinistra. This valvula in one case $(2.9 \%)$ had no nodulus at all. Also in one case $(2.9 \%)$ no noduli were observed on any of valvulae semilunares of the aortic valve.

\subsection{Ossa cordis}

Two ossa cordis are present in the fibrous ring of the aorta in the European bison; the right one is larger and the left is smaller (Phot. 11; Fig. 9, 18A, -79 and 80$)$.

Os cordis dext. (80) has a shape of a irregular triangle. In an adult individual, approximately 11 years old it was $5 \mathrm{~cm}$ long, $1.4 \mathrm{~cm}$ broad and $4.5 \mathrm{~mm}$ thick. Valvula semilunaris caudalis dextra of the aortic valve has its insertion on this bone. Os cordis sin. (79) is also triangular. Its dimensions in the above mentioned individual were: length $-2.3 \mathrm{~cm}$, width $-0.6 \mathrm{~cm}$, thickness $-3 \mathrm{~mm}$. Valvula semilunaris caudalis sinistra of the aortic valve has the insertion on this bone.

\section{DISCUSSION}

The heart of the European bison has many specific features which are not found in the most closely related species, Bos taurus dom. There are considerable differences in the size of the whole organ. The height of the heart is larger in the male bison than in the domestic bull while in females of both species the heart height is similar. The values of the largest and the smallest width indicate that the heart is more flat in the bison than in he cattle. The lenght of the anterior border of the heart is larger in the male bison than in the domestic bull while the length of the posterior border is smaller in the bison. The anterior border has approximately the same length in female bisons and in the domestic cows while the posterior border is much 14 - Acta theriol. 
shorter in the female bison (Table 8). The perimeter of the heart is much larger in the bison than in the cattle.

Observations and measurements indicate that the shape of the heart changes during the postnatal development of the European bison. The plane of the base of the ventricular part turns gradually and in adult individuals it is oblique, directed ventrally and to the right with respect to the long axis of the heart.

The mean absolute heart weight is much higher in the male bison than in the domestic bull. The relative weight of this organ, expressed in the per cent of body weight is also higher in the bison (Table 9).

Table 8.

Comparative listing of heart measurements in different species of Bovinae (in $\mathrm{mm}$ ).

\begin{tabular}{|c|c|c|c|c|c|c|}
\hline \multirow[b]{2}{*}{ No. } & \multirow[b]{2}{*}{ Measurements } & \multicolumn{3}{|c|}{$0^{\pi} 0^{\pi}$} & \multicolumn{2}{|c|}{ 우 $q$} \\
\hline & & Wisent & $\begin{array}{c}\text { Domestic } \\
\text { bull }^{1}\end{array}$ & Buffalo 2 & Wisent & $\begin{array}{c}\text { Domestic } \\
\text { cow }^{1}\end{array}$ \\
\hline 1 & Height (the left surface) & $186-234$ & $150-180$ & 198 & $175-188$ & $170-220$ \\
\hline 2 & Maximal width & $189-237$ & $174-199$ & 161 & $199-201$ & $180-195$ \\
\hline 3 & Minimal width & $124-160$ & $130-140$ & 122 & $144-155$ & $125-150$ \\
\hline 4 & $\begin{array}{l}\text { Length of the anterior } \\
\text { border }\end{array}$ & $225-285$ & $188-203$ & - & $212-213$ & $192-220$ \\
\hline 5 & $\begin{array}{l}\text { Length of the posterior } \\
\text { border }\end{array}$ & $167-190$ & $173-203$ & - & $137-172$ & $186-203$ \\
\hline 6 & $\begin{array}{l}\text { Circumference (below the } \\
\text { coronary groove) }\end{array}$ & $525-682$ & $480-529$ & 475 & 594-597 & $475-517$ \\
\hline
\end{tabular}

1 - Acc. to Schubert (1909); 2 - Acc. to Albrecht (1957).

Table 9.

Comparison of the heart weight of European bison (wisent) and domestic cattle.

\begin{tabular}{|l|c|c|c|c|}
\hline \multirow{2}{*}{ Species } & $\begin{array}{c}\text { Body wt. } \\
(\mathrm{kg})\end{array}$ & \multicolumn{2}{|c|}{ Avg. heart wt. } & \multicolumn{1}{|c|}{ Author } \\
\cline { 3 - 5 } & Abs. (kg) & Relative $\%$ & \\
\hline Domestic bull & $370-895$ & 2.592 & 0.442 & S c h n e i d e r, 1904 \\
Domestic bull & $485-775$ & 2.750 & 0.436 & S c h u b e r t, 1909 \\
Wisent (males) & $470-750$ & 3.057 & 0.495 & Original data \\
\hline
\end{tabular}

The higher relative heart weight in the bison is undoubtedly related to the different mode of living of this species, as compared with domestic cattle. Strong development of the sceletal musculature in the bison ( $\mathrm{Sw}$ iéżński, 1962) and the character of its locomotory efficiency (on which the heart weight depends according to $\mathrm{P}$ oplew$\mathrm{sk} \mathrm{i,} \mathrm{1948)} \mathrm{have} \mathrm{also} \mathrm{a} \mathrm{significant} \mathrm{role.}$

Moreover, many anatomical and morphological characteristics are different in the heart of the European bison than in the heart of domestic cattle. These differences are listed in table 10. It is worth 
Table 18.

Listing of some differences in the morphology of the heart in European bison, domestic cattle and other ruminants. Last two cases - acc. to different authors refered by number acc. to references.

\begin{tabular}{|c|c|c|c|}
\hline Character & European bison & Domestic cattle & Other ruminants \\
\hline 1 & 2 & 3 & 4 \\
\hline $\begin{array}{l}\text { 1. Topography of the } \\
\text { heart. } \\
\text { A. The base of the } \\
\text { ventricles (the widest } \\
\text { part) }\end{array}$ & $\begin{array}{l}\text { 3rd-6th rib posterior borders. } \\
\text { Sometimes shifted anteriorly, one } \\
\text { width of a rib or posteriorly, one } \\
\text { width of an intercostal space. }\end{array}$ & $\begin{array}{l}\text { 3rd-5th rib }(2,15,17) \text {. According } \\
\text { to some authors }(2,14) \text { the poster- } \\
\text { ior heart border may reach } 6 \text { th } \\
\text { rib. }\end{array}$ & \\
\hline B. The apex. & 7 th-8th costal cartilagines. & $\begin{array}{l}\text { 5th costal cartilago }(2,17,15) \text {. } \\
\text { Some authors place the heart apex } \\
\text { on the level of the 6th costal car- } \\
\text { tilago (34). }\end{array}$ & \\
\hline $\begin{array}{l}\text { 2. Line of transition } \\
\text { of lamina visceralis } \\
\text { pericardii into lamina } \\
\text { parietalis pericardii. }\end{array}$ & $\begin{array}{l}\text { Usually on the whole left surface } \\
\text { of the heart along a. pulmonalis. }\end{array}$ & $\begin{array}{l}\text { Variable course; along the aorta } \\
\text { and then posteriorly along a. pul- } \\
\text { monalis, or exclusively along a. } \\
\text { pulmonalis }(15,17) \text {. }\end{array}$ & \\
\hline $\begin{array}{l}\text { 3. Lig. sternopericar- } \\
\text { diacum dextrum }\end{array}$ & $\begin{array}{l}\text { Insertion on the sterum at the } \\
\text { level of the 6th costal cartilago. }\end{array}$ & Both ligaments are inserted at the & \\
\hline $\begin{array}{l}\text { 4. Lig. } \\
\text { sternopericar- } \\
\text { diacum } \\
\text { sinistrum }\end{array}$ & $\begin{array}{l}\text { Insertion on the sternum at the } \\
\text { level of } 6 \text { th - } 7 \text { th costal cartilagi- } \\
\text { nes. }\end{array}$ & $\begin{array}{l}\text { (21). According to other authors } \\
(14,15,34) \text { on the level of the } 6 \text { th } \\
\text { costal cartilago. }\end{array}$ & \\
\hline $\begin{array}{l}\text { 5. Length of both lig. } \\
\text { sternopericardiaca }\end{array}$ & $2-5 \mathrm{~cm}$ & $1-2 \mathrm{~cm}(15)$ & \\
\hline $\begin{array}{l}\text { 6. Lig. phrenicoperi- } \\
\text { cardiacum }\end{array}$ & Present & Was not described & \\
\hline
\end{tabular}




\begin{tabular}{|c|}
\hline 1 \\
\hline $\begin{array}{l}\text { 7. The shape of the } \\
\text { heart }\end{array}$ \\
\hline $\begin{array}{l}\text { 8. Position of conus } \\
\text { arteriosus dexter }\end{array}$ \\
\hline $\begin{array}{l}\text { 9. Proximal part of } v \text {. } \\
\text { cava cranialis }\end{array}$ \\
\hline $\begin{array}{l}\text { 10. Distal parts of } v \text {. } \\
\text { cordis magna and } v \text {. } \\
\text { azygos sinistra. }\end{array}$ \\
\hline $\begin{array}{l}\text { 11. Orifice of sinus si- } \\
\text { nister (vv. pulmona- } \\
\text { les). }\end{array}$ \\
\hline
\end{tabular}

12. Sinus dexter (vv. pulmonales).

13. Proximal parts of vv. pulmonales.

14. Sulcus longitudinalis accessorius.

\section{2}

Cone-shaped. This cone is relatively low, widened at the base and markedly flattened laterally. Its apex is usually bent slightly posteriorly.

High in relation to the base of the heart ventricle.

$\sigma^{*}$ - stranger than $v$. cava caudalis.

우 - weaker than v. cava caudalis.

Covered with myocardium.

Usually on the dorsal wall of left atrium. In 6 cases $(24.9 \%)$ on the lateral or dorso-lateral wall.

Uniform.

Covered with myocardium.

Usually ends on the heart apex. In 8 cases $(22.8 \%)$ it was ending in the middle of the left ventricle height. 
Cone-shaped: The cone is elongated, narrow, and slightly flattened $(3,15,44)$.

In the buffalo (44) and the mountain sheep $(24,25)$ the shape of the heart resembles that of the European bison.

Low; does not seem to exceed pars ventricularis $(2,15,34)$.

High in the sheep $(6,16)$ and markedly high in the mouflon (30) and the deer (35).

In the buffalo (3) the diameter of both vessels is approximately the same.

In the yak (3) both vessels have the same diameter.

Not covered (12).

Lateral wall of the left atrium (10).

Sheep - on the dorsal wall of left atrium (10).

Double (44).

Not covered (42).

Does not reach the heart apex $(14,34)$.

In wild-living ruminants (Bovidae) it ends $3-4 \mathrm{~cm}$ above the heart apex (3). 


\begin{tabular}{|c|c|c|c|}
\hline 1 & 2 & 3 & 4 \\
\hline $\begin{array}{l}\text { 15. } M m \text {. pectinati of } \\
\text { the dorsal wall of au- } \\
\text { ricula dextra. }\end{array}$ & $\begin{array}{l}\text { Flat and thin with shallow sulci } \\
\text { in between. }\end{array}$ & $\begin{array}{l}\text { Thick trabecula carnea, the so } \\
\text { called dendrous pillar ( } 27) \text {. }\end{array}$ & \\
\hline $\begin{array}{l}\text { 16. The occurrence of } \\
\text { foramen ovale. }\end{array}$ & Only until the $42-$ nd day of life. & $\begin{array}{l}\text { Until the 20th day of life (19). Can } \\
\text { be present during the whole life } \\
\text { in } 20-22 \%(14,44) \text {. Occurs in } 23^{\circ} \% \\
\text { of young individuals and in } 16^{\circ} \% \\
\text { of old ones }(2,15) \text {. }\end{array}$ & $\begin{array}{l}\text { Sheep until the } 10 \text { th day of life } \\
\text { (18). }\end{array}$ \\
\hline $\begin{array}{l}\text { 17. Number of cusps } \\
\text { in valva tricuspidalis. }\end{array}$ & $3-7$ most frequently 4 . & $\begin{array}{l}\text { Most often } 3(40 \%) \text { or } 6(36 \%), \text { less } \\
\text { frequently } 4(24 \%)(36) \text {. }\end{array}$ & \\
\hline $\begin{array}{l}\text { 18. Number of types of } \\
\text { valva tricuspidalis. }\end{array}$ & 5 & $1(44)$ & \\
\hline $\begin{array}{l}\text { 19. Number of cusps } \\
\text { in valva bicuspidalis. }\end{array}$ & $\begin{array}{l}4-9, \text { most frequently } 6(40 \%) \text {, less } \\
\text { often } 5 \text { or } 7(22.8 \% \text { of each). }\end{array}$ & $\begin{array}{l}\text { Most frequently } 5\left(64^{\circ} / 0\right) \text {, less often } \\
6\left(20^{\circ} \%\right) \text { or } 4\left(16^{\circ} \%\right)(36) \text {. }\end{array}$ & \\
\hline $\begin{array}{l}\text { 20. Number of types } \\
\text { of valva bicuspidalis. }\end{array}$ & 13 & $2(44)$ & \\
\hline $\begin{array}{l}\text { 21. Number of chordae } \\
\text { tendineae extending } \\
\text { from septum interven- } \\
\text { triculare to cuspis sep- } \\
\text { talis valvae tricuspi- } \\
\text { dalis. }\end{array}$ & $\begin{array}{l}2-9 \text { in } 20 \text { cases }(60.6 \%) \text { absent in } \\
\text { the remaining cases. }\end{array}$ & $\begin{array}{l}\text { Were not described (only in one } \\
\text { specimen of steppe cattle } 6 \text { chor- } \\
\text { dae tendineae were found) (3). }\end{array}$ & $\begin{array}{l}\text { Often occur in sheep (4) roe- } \\
\text {-deer (39) and deer ( } 35) \text {. }\end{array}$ \\
\hline $\begin{array}{l}\text { 22. Noduli valvularum } \\
\text { semilunarum in the } \\
\text { valve of } a . \text { pulmonalis. }\end{array}$ & $\begin{array}{l}\text { Strongly pronounced in } 86 \% \text { of } \\
\text { the studied } 105 \text { individuals. }\end{array}$ & Present in $47-50 \%(14,41)$. & Sheep - present in $70 \%$ (41). \\
\hline $\begin{array}{l}\text { 23. Noduli valvularum } \\
\text { semilunarum of the } \\
\text { aortic valve. }\end{array}$ & $\begin{array}{l}\text { Well developed in approximately } \\
85 \% \text { of the studied } 105 \text { cases. }\end{array}$ & Present in $65-100 \%(14,41)$. & Sheep - present in $83 \%$ (41). \\
\hline $\begin{array}{l}\text { 24. Trabeculae carneae } \\
\text { extending from coni } \\
\text { of mm. papillares of } \\
\text { the left ventricle. }\end{array}$ & Usually present. & $\begin{array}{l}\text { No data in available literature } \\
\text { [Only in steppe cattle trabecula } \\
\text { carnea extending from one of the } \\
\text { papillary muscles was described } \\
\text { (3)]. }\end{array}$ & $\begin{array}{l}\text { Such trabeculae were described } \\
\text { in sheep (4). }\end{array}$ \\
\hline
\end{tabular}


mentioning that all studied bisons (14) had lig. phrenicopericardiacum. To the best of my knowledge an analogous ligament was never described in domestic cattle. Only Martin \& Schauder (1933) made a rather general statement that in this species pericardium is also connected with the diaphragm.

Table 11.

Comparison of the measurements (height -1 , circumference -2 ) of the pulmonary and aortic valves of the wisent and cattle (in $\mathrm{mm}$ ).

\begin{tabular}{|c|c|c|c|c|}
\hline \multicolumn{3}{|c|}{ Valve } & Wisent & $\begin{array}{l}\text { Cattle } \\
\text { (acc. to Schubert, 1909) }\end{array}$ \\
\hline \multirow{3}{*}{ 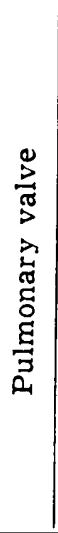 } & V. semilunaris cranialis dex. & 2 & $\begin{array}{c}28-39 \\
32 \\
65-77 \\
72\end{array}$ & $\begin{array}{l}25 \\
58\end{array}$ \\
\hline & V. semilunaris cranialis sin. & 2 & $\begin{array}{c}29-40 \\
31 \\
70-86 \\
75\end{array}$ & $\begin{array}{l}26 \\
66\end{array}$ \\
\hline & V. semilunaris caudalis & 2 & $\begin{array}{c}28-39 \\
31 \\
71-81 \\
75\end{array}$ & $\begin{array}{l}23 \\
70\end{array}$ \\
\hline \multirow{3}{*}{ 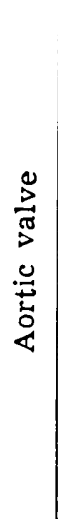 } & V. semilunaris cranialis & 1 & $\begin{array}{c}22-27 \\
23 \\
75-85 \\
79\end{array}$ & $\begin{array}{l}28 \\
59\end{array}$ \\
\hline & V. semilunaris caudalis dex. & 2 & $\begin{array}{c}27-37 \\
31 \\
75-82 \\
78\end{array}$ & $\begin{array}{l}33 \\
62\end{array}$ \\
\hline & V. semilunaris caudalis sin. & 1 & $\begin{array}{c}27-33 \\
30 \\
69-79 \\
74\end{array}$ & $\begin{array}{l}27 \\
68\end{array}$ \\
\hline
\end{tabular}

Myocardium of pars atrialis in the bison covers proximal parts of venae which open to both atriums. It is well pronounced on venae opening into sinus coronarius and on $v v$. pulmonales and must markedly promote efficient drainage of blood from the coronary circulation and the afflux of blood to the left atrium. In the cattle myocardium 
covers only the sinuses of the left atrium ( $Z$ e d e nov, 1939). W inte rs te in (1933) described two layers of myocardium in the calf occuring around the right $v v$. pulmonales but this must have been the myocardium surrounding sinus dexter, which was not differentiated by this author.

As indicated in table 10 , both valva tricuspidalis and valva bicuspidalis have a variable number of cusps. These variations concern predominantly the accessory cusps which may occur in different number. Occasionally accessory cusps attain large dimensions and play an important role in closing the atrio-ventricular orifices. Albrecht (1957) studied the bison heart but did not describe any accessory cusps in the atrio-ventricular valves. According to this author cuspis caudalis is the largest in the tricuspid valve. The present study did not confirm this observation; cuspis caudalis was not always the largest (cf. Fig. 10).

Chordae tendineae extending directly from the ventricular septum were often found in the bison heart. They were noted in the sheep and in wild-living ruminants but not in domestic cattle. In the latter species cuspis septalis of the tricuspid valve receives chordae tendineae from $\mathrm{mm}$. pectinati.

Noduli valvularium semilunarium of the pulmonary valve and the aortic valve were present in approximately $85 \%$ of the studied bisons being more stable than in other ruminants. Valvulae semilunares of these two valves are larger in the bison than in the domestic cattle (cf. table 11). The only exception was valvula semilunaris cranialis of the aortic valve which is much shorter in the bison. This indicates that the dorsal border of the ventricular septum (on which it is inserted) is protruding markedly into the lumen of the aortic orifice.

The lateral walls and the ventricular septum were thicker in the European bison than they are in the cattle according to $\mathrm{H}$ a h $\mathrm{n}$ (1908) and $\mathrm{Martin} \& \mathrm{Sch}$ a uder (1938).

The size of ossa cordis in the European bison (studied in one 11 year old male) was within the range reported for the domestic bull ( $\mathrm{Ch}$ ojc i j a n, 1956).

Acknowledgments: The author wishes to express his deep gratitude to Professor K. Krysiak for suggesting this problem for the doctoral dissertation and continuous help throughout the study.

\section{REFERENCES}

1, A ckerkne cht E., 1918: Die Papillarmuskel des Herzens. Arch. Anat. Phys., Anat. Abt., 64-130, Leipzig.

2. A ckerknecht E., 1943: Das Herz. [In „Ellenberger-Baum, Handbuch der vergleichenden Anatomie der Haustiere"]. 1: 610-627, Springer Verl., Berlin. 
3. Albrecht R., 1957: Zur Anatomie des Bovidenherzens. (Untersuchungen am Yak, Wisent, Bison, Indischen Büffel, Zebu, Zwergzebu und Steppenrind). Morphol. Jahrb., 98: 575-605, Akad. Verl. Geest \& Partig. Leipzig.

4. Ang s t J., 1928: Das Herz des Hausschafes (Ovis aries L.). Morph. Jahrb, 59: 209-252. Akad. Verl., Jena.

5. Chojcijan R. N., 1956: Fibroznyj skielet serdca bujvola. Tr. Erev. Zoovet. Inst., 20: 115-122. Erevan.

6. Drechsel J., 1928: Zur Architektur der Herzkammerwände. Z. Anat., 87: 29-44, F. J. Bergmann. München.

7. Empel W. \& Roskosz T., 1963: Das Skelett der Gliedmassen des Wisents, Bison bonasus ( $\mathrm{L}$ i n $\mathrm{n}$ a e u s, 1758). Acta theriol., 7: 260-299. Białowieża.

8. Frick H., 1956: Morphologie des Herzens. Hdb. Zool., 8: 1-48, W. Gruyter. Berlin.

9. Gschwend T., 1931: Das Herz des Wildschweines. Anat. Anz., 72: 49-89. Jena.

10. Guzsal E., 1955: The topography of the blood vessels and of the bronchial tree of the domestic animals. Acta vet., 5: 333-365. Budapest.

11. Hahn A. W., 1908: Beitrag zur Anatomie der Kammerscheidewand unserer Haustiere. Diss., 1-36. Bern.

12. H e gazi H., 1958: Die Blutgefässversorgung des Herzens von Rind, Schaf und Ziege. Diss., 776-819. W. Greve, Gissen.

13. H u v ler B., 1926: Zur Anatomie des Schweinesherzens. Anat. Anz., 62: 4976. Jena.

14. Klimow A. \& A kajew ski A., 1960: Anatomia zwierząt domowych. 2: 146-202. Państw. Wyd. Roln. i Leśn. Warszawa.

15. Martin P. \& Schauder W., 1938: Anatomie der Haustiere. 3: 378-426, Schickhardt \& Ebner. Stuttgart.

16. M a y N. D. S., 1955: The anatomy of the sheep. 1: 1-167, Queensl. Press. Brisbane Q.

17. Nickel R., Schummer A. \& Seiferle E., 1960: Lehrbuch der Anatomie der Haustiere. 2: 1-411, P. Parey. Berlin und Hamburg.

18. Ogorodnikov V. J., 1964: Vozrastnye izmenenja serdca Kazahskih tonkorunnyh ovec. Indiv. Rozv. Sh. Živ., 1: 82-86. Alma-Ata.

19. Ottaway C. W., 1944: The anatomical closure of the foramen ovale in the lguine and bovinae heart. Veter. Jr., 100: Baillière \& Tindall \& Cassell. (Cited after Żedenov, 1961).

20. Palmgren A., 1928a: Herzgewicht und Weite der Ostia atrioventricularia des Rindes. Anat. Anz., 65: 333-342. Jena.

21. Palmgren A., 1928b: Zur Anatomie und Entwicklungsgeschichte des Mittelfelles (Mediastinum der Haussäugetiere). Z. Anat. Entw., 87: 368-409. Jena.

22. Piękoś M., Pilarski W. \& Roskosz T., 1958: Obserwacje nad długością jelita u żubra - Bison bonasus L. Folia morph., 1: 69-79. Warszawa.

23. Pilarski W., Serwatka S., Swieżyński K. \& Węgrzyn M., 1967: New attempts at fixing anatomical material of large mammals. Acta theriol., $12,31: 453-458$.

24. Plemiannikov A. G., 1954a: Morfologičeskie osobennosti serdca u ovec porody kazahskij arharomerinos. Tr. Inst. Eksp. Biol., 2: 23-37. Alma-Ata. 
25. Plemiannikov A. G., 1954b: Morfologičeskie osobennosti serdca kazahskih tonkorunnyh ovec $\mathrm{i}$ ih ishodnyh form $\mathrm{i}$ novoj porodnoj gruppy priaralskih tonkorunnyh. Tr. Int. Eksp. Biol., 2: 94-112. Alma-Ata.

26. Plemiannikov A. G., 1954c: Morfologičeskie osobennosti serdca kazahskih šerstnyh koz $\mathrm{v}$ sravnenii $\mathrm{s}$ ishodnymi formami. Tr. Inst. Eksp. Biol., 2: 193-206. Alma-Ata.

27. Poplewski R., 1929: Mięśnie grzebieniaste serca. Diss, 1-143, Tow. Nauk. War. Warszawa.

28. Poplewski R., 1948: Anatomia ssaków. 4: 151-215, Czytelnik. Stockholm.

29. Preus s F., 1956: Zur Nomenklatur am Herzen. Anat. Anz., 103: 20-37. Jena.

30. Rollh äuser H., 1943: Uber Gestalt und Bedeutung der Herzohren. Gegenb. Morph. Jb., 88: 249-267. Leipzig.

31. Schneider J., 1904: Gewicht von Organen des Rindes. Z. Fleisch- und Milchh., 14: 393-398. Berlin.

32. Schubert F., 1909: Beiträge zur Anatomie des Herzens der Haussäugetiere. Diss., 1-90, O. Franke. Dresden.

33. Schwartz G., 1911: Untersuchungen über das Sinunsgebiete im Wiederkäuerherzen. Arch. Wiss. Thierheilk., 37: 152-178. Berlin.

34. Sisson S. \& Grossman J., 1960: The anatomy of the domestic animals. I: 718-732, W. B. Saunders Co. Philadelphia and London.

35. Spangl S., 1932: Adatok a szarvas szivenek anatomiájáhaz (Zur Anatomie des Hirschherzens). Diss., 1-32, Patria. Budapest.

36. Steinmüller G., 1910: Uber die Segel- und Taschenklappen unserer Haussäugetiere. Diss., 1-54. Bern.

37. Swieży ński K., 1962: Skeletal muskulatural system of the european bison, Bison bonasus (L i n n a u s, 1758). Acta theriol., 6: 113-164. Białowieża.

38. Vermes E., 1926: Zur Sektionstechnik des Herzens. Anat. Anz., 60: 395-405. Jena.

39. W a $1 \mathrm{dm}$ e i e E E., 1928: Das Rehherz (Cervus capreolus L.). Morph. Jahrb., 59: 567-598. Leipzig.

40. Winterstein J., 1933: Untersuchungen über die Verhofsmuskulatur. Z. Anat. Entw., 99: 721-734. Berlin.

41. Witzeman $\mathrm{n}$ S., 1923: Uber die noduli valvularum semilunarium und ihre physiologische Bedeutung bei unseren Haustiere. Diss., 1-39, W. Kersten. Bern.

42. Ž edenov V. N., 1939: Anatomičeskie strojenie, formirovanie i vozrastnye izmenenija otverstii i klapannyh apparatov serdca krupnogo rogatogo skota i drugih domašnyh životnyh. Diss. Ckalov. (Cited after Ž edenov, 1961).

43. Żedenov W. N., 1941: Novye dannye o stroenii i rastenii otvierstii i klapannyh apparatov serdca vysšyh placentarnyh živitnyh i čeloveka. Tr. Ckal. S-ch. Inst., 1: 53-74. Ckalov.

44. Žedenov W. N., 1961: Legkie i serdce životnyh i čeloveka. Diss., 215-426, Gos. Izd. Moskva.

Received, August 5, 1967.

Warsaw Agricultural University, Department of Animal Anatomy, Warszawa, Grochowska 272. 
Mieczysław WEGRZYN

UKEAD KRWIONOŚNY ŻUBRA. I. MORFOLOGIA SERCA

\section{Streszczenie}

Badano położenie, stosunki osierdziowe, kształt, wielkość i ciçżar oraz budow̨ morfologiczną z uwzględnieniem pomiarów serca u 37 żubrów różnej płci i wieku.

Serce żubra najczęściej zajmuje przestrzeń zawartą między tylnymi krawędziaımi 3 i 6 żebra. Obserwowano przesunięcia ku przodowi o szerokość jednego żebra lub ku tyłowi o szerokość jednej przestrzeni międzyżebrowej. Wierzcholek serca układa się na wysokości 7-8 chrząstki żebrowej. Osierdzie umocowane jest do mostka za pomocą dwóch więzadel mostkowo-osierdziowych (przyczepiających się na wysokości 6-7 chrząstki żebrowej) i jednego więzadla osierdziowo-przeponowego (Rys. 3).

Serce dorosłego żubra posiada ksztalt silnie rozszerzonego u podstawy, stosunkowo niskiego, wyraźnie bocznie spłaszczonego stożka (Fot. 2, 5, 8), zazwyczaj z wygiętym nieco ku tyłowi wierzchołkiem. Stożek tętniczy prawy jest wysoko ustawiony, w porównaniu z częścią wlaściwą komory prawej (Fot. 7, - 62). Wymiary serca są znacznie większe u żubra niż u bydla. Wyjątek stanowi krawędź tylna, której długość u żubra jest wyraźnie mniejsza (Tabela 8). Sredni ciężar sercá u samców żubra wynosi $3,057 \mathrm{~kg}\left(0,495^{\%} /\right.$ ciężaru ciała) (Tabela 3, 9). Zatok żyl płucnych jest trzy. Zatoka lewa $z$ reguły uchodzi na grzbietowej ścianie do przedsionka lewego.

Zastawka przedsionkowo-komorowa prawa zbudowana jest $z$ 3-7 płatów. Najczęściej występują 3 płaty główne i 1 dodatkowy - tylny. (Ryc. 10; Tabela 4). Zastawka przedsionkowo-komorowa lewa składa się z dwóch płatów głównych i 2 dodatkowych. Ostatnie mogą przyjmować duże rozmiary, jak również ulegać podziałowi na wtórne płatki. Łączna liczba płatów i płatków wynosi 4-9 (Ryc. 11, Tabela 4). W komorze prawej stwierdza się obecność strun ścięgnistych odchodzących bezpośrednio z przegrody międzykomorowej (Ryc. 12, $-60^{\prime}$ ). Są one przeznaczone do płata przegrodowego zastawki trójdzielnej. Grudki płatów półksiężycowych są wyraźnie wykształcone w zastawce tętnicy płucnej w $86 \%$, a w zastawce aorty w 85\%. Oba mięśnie brodawkowate komory lewej z reguły wysyłają silne beleczki mięśniowe (lub stożki ze strunami) do ściany bocznej komory, w miejscu umocowania płatów zastawki dwudzielnej (Fot. 13; Ryc. 18, B, C). 


\section{EXPLANATION OF PLATES}

Plate I.

Phot. 1. Organs of the thoracic cavity of the bison ( $\sigma^{\prime}$, Putar, 6 years old); left view. A - the apical lobe of the right lung, B - the left lung, a - the apical lobe, b the cardiac lobe, $\mathrm{c}$ - the diaphragmatic lobe, $\mathrm{C}-$ the heart in pericardium.

Phot. 2. Position of the heart in the thoracic cavity of the European bison ( $\sigma^{\star}, \mathrm{Pu}-$ tar, 6 years old); left view. The left lung and part of pericardium were removed. A - the apical lobe of the right lung, $C^{\prime}$ - heart.

Phot. 3. Organs of the thoracic cavity of the bison ( $\sigma^{*}$, Zon, 1 year old); right view. A - right lung, a - apical lobe, b - cardiac lobe, c - diaphragmatic lobe, C heart in pericardium.

Phot. 4. The attachement of the heart and pericardium in the thoracic cavity ( $q$, Beste, 23 years old); left view.

Plate II.

Heart of the European bison ( $\sigma^{7}$, Putar, 6 years old).

Phot. 5. The left surface.

Phot. 6. The right surface. Phot. 7. Viewed from the side of the anterior border. Phot. 8. Viewed from the side of the posterior border.

\section{Plate III.}

Phot. 9. The right auricle of the bison ( $\sigma^{*}$, Putar, 6 years old); lateral wall of the auricle cut to show $\mathrm{mm}$. pectinati.

Phot. 10. The left auricle of the bison ( $\sigma$, Putar, 6 years old); viewed from the internal surface.

Phot. 11. Ossa cordis of the bison ( $\sigma^{*}$, Stor-per, 111/2 years old); dorsal view.

Phot. 12. Trabeculae carneae of the right ventricle, below the tricuspid valve in the bisons heart ( $\sigma^{\prime}$, Pusłon, $4^{1 / 2}$ years old).

Phot. 13. Trabeculae carneae on the posterior wall of the left ventricle ( $\sigma^{*}$, Pusłon, $41 / 2$ years old). Two of these are extending from the apices of $\mathrm{mm}$. papillares. Trabecula of $m$. papillaris sinister has a tendency to divide. 


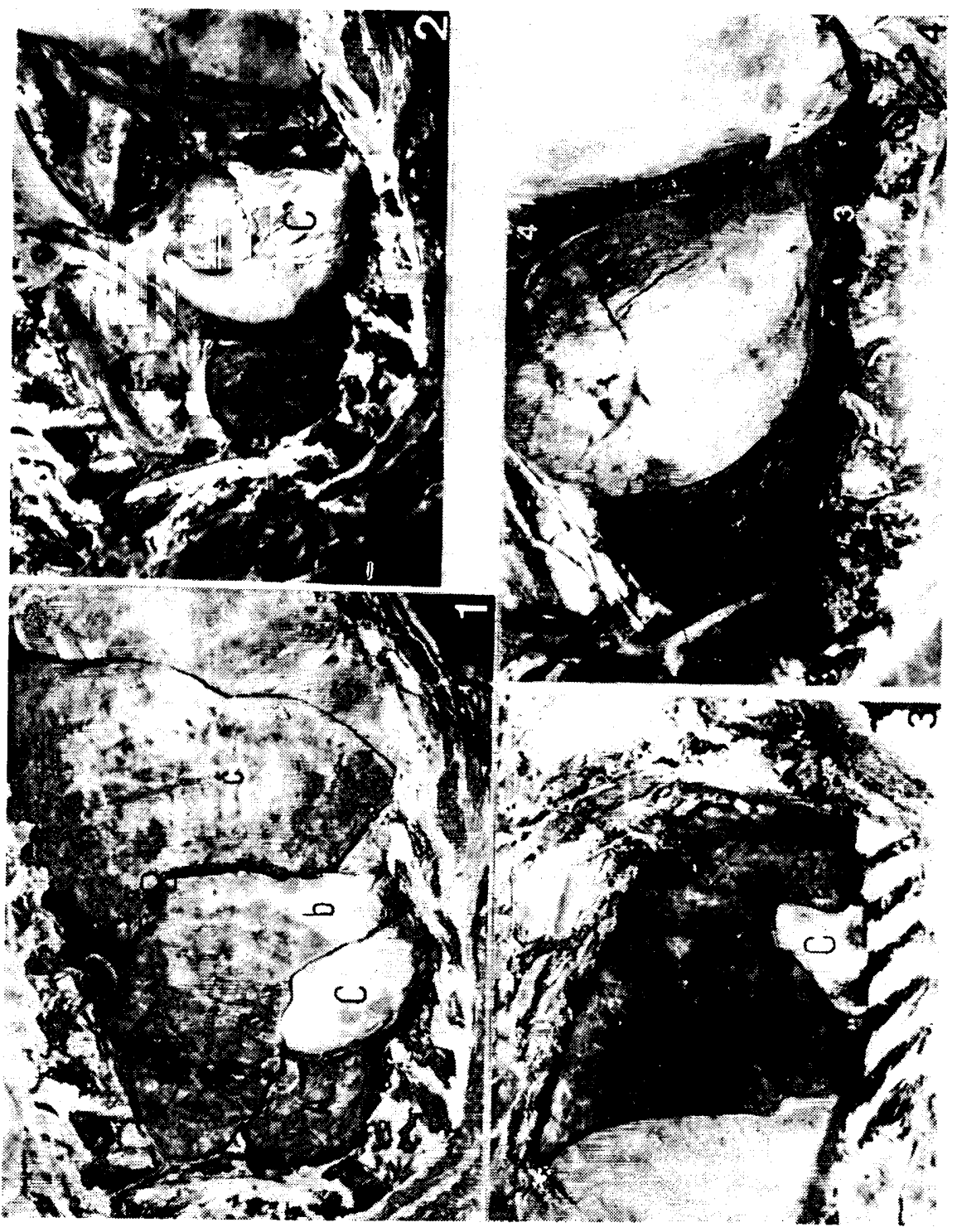



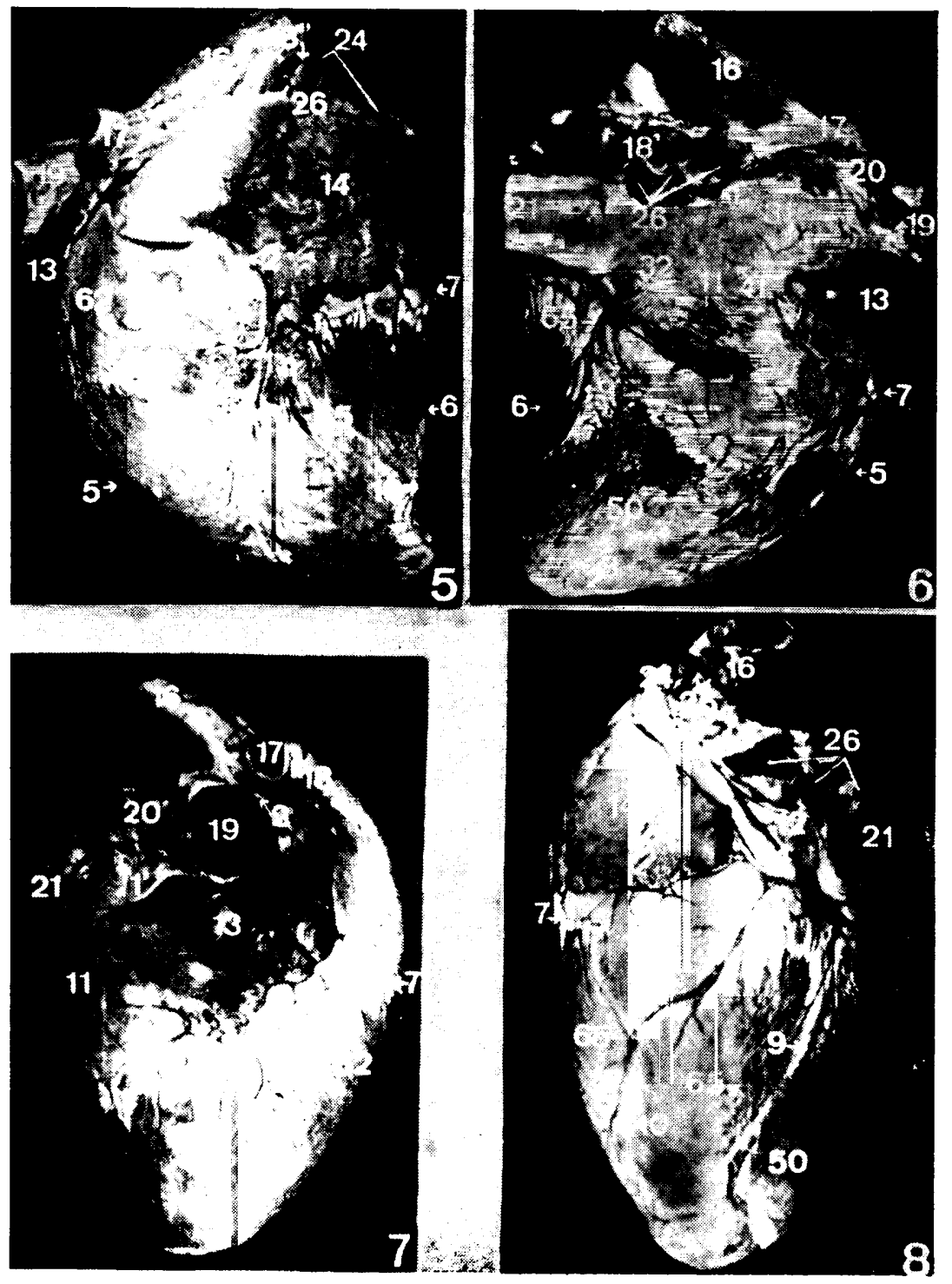


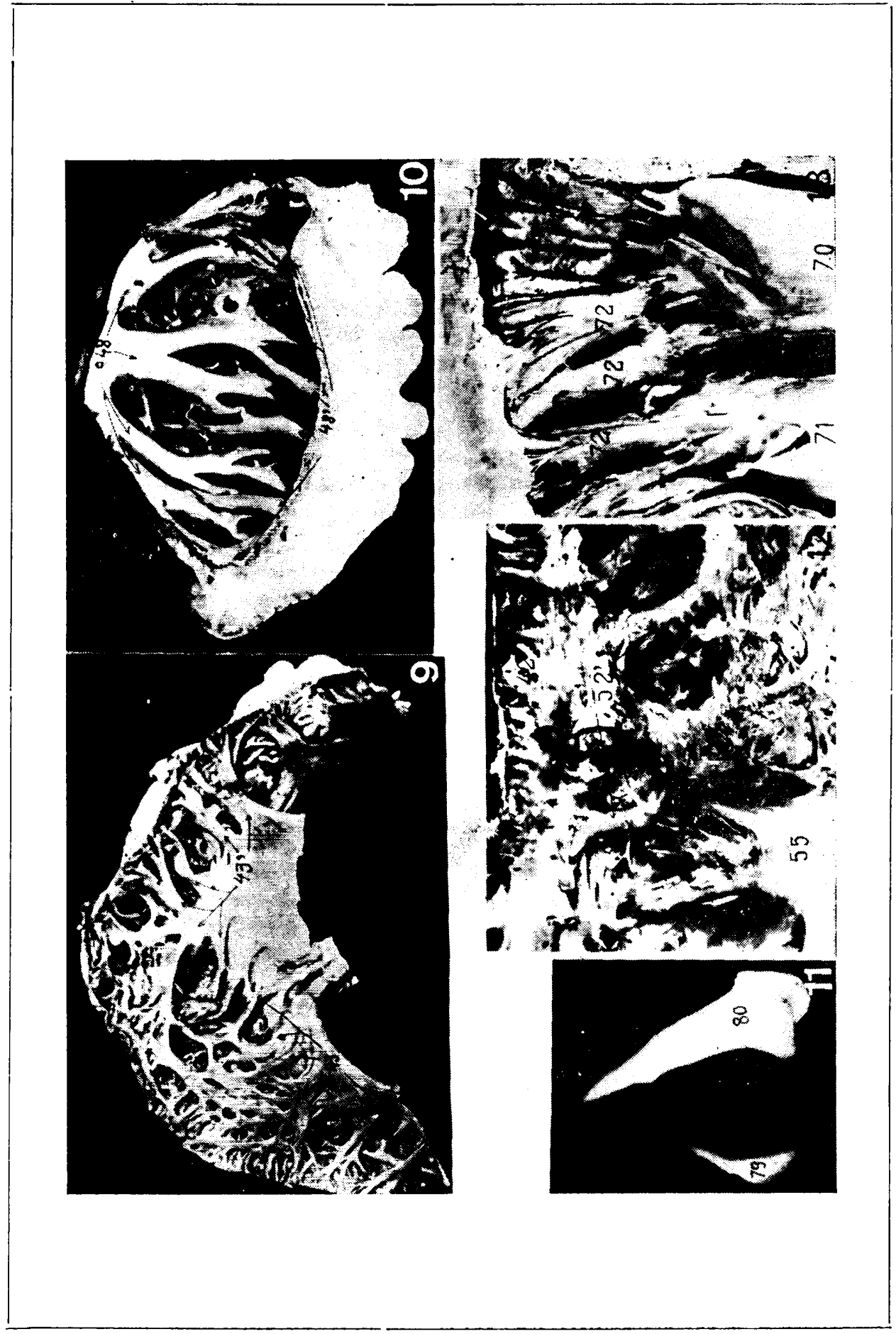


KEY TO THE NUMBERS OF THE FIGURES

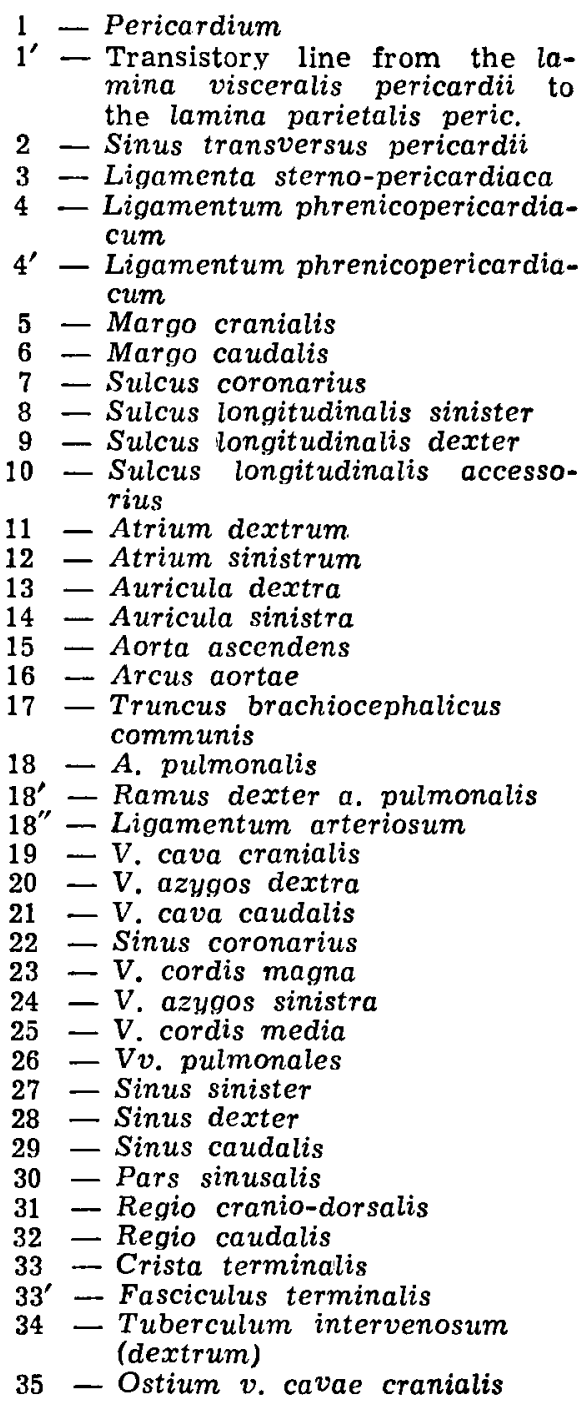

\author{
36 - Septum interatriale \\ 37 - Ostium v. cavae caudalis \\ 38 - Ostium sinus coronarii \\ 39 - Lamina valvuloidea \\ 40 - Pars propria atrii \\ 41 - Sulcus terminalis \\ $42-M m$. pectinati (of the right \\ atrium) \\ $43:-M m$. pectinati $\}$ of the right auricle \\ 43: - Mm. pectinati \\ 45 - Limbus fossae ovalis \\ 46 - Tuberculum intervenosum (si- \\ nistrum) \\ $46^{\prime}$ - Tuberculum intervenosum (si- \\ nistrum) \\ 17 - Chordae tendineae of the fora- \\ men ovale valve \\ 48 - $-M m$. pectinati $\}$ pectinati $\}$ of the right auricle \\ 49 - The falciform fold \\ 50 - Ventriculus dexter \\ 51 - Ventriculus proprius \\ 52 - Trabeculae carneae \\ $52^{\prime}$ - Trabeculae carneae \\ 53 - Ostium atrioventriculare dex- \\ trum \\ $53^{\prime}$ - Myocardium of the right atrium \\ exceeding to the tricuspid valve \\ 54 - Valva tricuspidalis \\ 54a - Cuspis septalis \\ 54b - Cuspis cranialis \\ 54c - Cuspis caudalis \\ 54d - Cuspis accessorius caudalis \\ $54 \mathrm{e}-$ Cuspis accessorius cranialis \\ $54 f$ - Cuspis accessorius lateralis \\ 55 - $M$. papillaris cranialis \\ $5^{\prime}-M$. papillaris cranialis (apex) \\ $56-M$. papillaris subarteriosus \\ 57 - M. papillaris caudalis dexter \\ 58 - M. papillaris accessorius \\ 59 - Mm. papillares proprii septales \\ b0 - Chordae tendineae ( $\mathrm{mm}$. papil- \\ lares) \\ $60^{\prime}$ - Chordae tendineae of the ven- \\ tricular septum
}

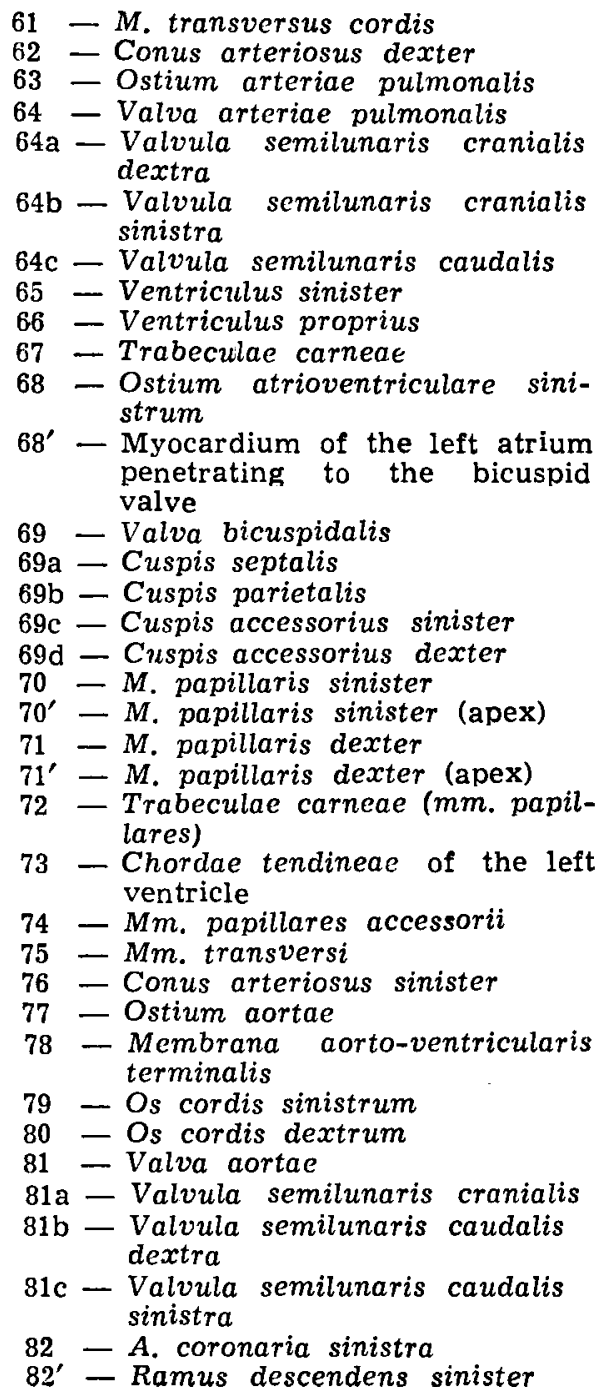

